RFP-2644

July 14,1977

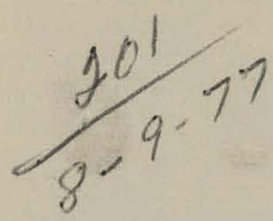

RFP-2644

July 14, 1977

\title{
QUALITY ENGINEERING AND CONTROL \\ SEMIANNUAL PROGRESS REPORT NOVEMBER AND DECEMBER 1976 AND
}

JANUARY THROUGH APRIL 1977

\section{SERVICE LABORATORIES GROUP}

Robert L. Carpenter

Atomics International Division

Rocky Flats Plant

P.O. Box 464

Golden, Colorado 80401 


\section{DISCLAIMER}

This report was prepared as an account of work sponsored by an agency of the United States Government. Neither the United States Government nor any agency Thereof, nor any of their employees, makes any warranty, express or implied, or assumes any legal liability or responsibility for the accuracy, completeness, or usefulness of any information, apparatus, product, or process disclosed, or represents that its use would not infringe privately owned rights. Reference herein to any specific commercial product, process, or service by trade name, trademark, manufacturer, or otherwise does not necessarily constitute or imply its endorsement, recommendation, or favoring by the United States Government or any agency thereof. The views and opinions of authors expressed herein do not necessarily state or reflect those of the United States Government or any agency thereof. 


\section{DISCLAIMER}

Portions of this document may be illegible in electronic image products. Images are produced from the best available original document. 


\section{LEGAL NOTICE}

This report was prepared as an account of work sponsored by the United States Government. Neither the United States nor the Energy Research and Development Administration, nor any of their employees, nor any of their contractors, subcontractors, or their employees, makes any warranty, expressed or implied, or assumes any legal liability or responsibility for the accuracy, completeness or usefulness of any information, apparatus, product or process disclosed, or represents that its use would not infringe privately owned rights.

Printed in the United States of America

Available from the

National Technical Information Service

U. S. Department of Commerce

Springfield, Virginia 22161

Price: Printed Copy $\$ 50$ Microfiche $\$ 3.00$

Price Is Subject to Change Without Notice 


\section{QUALITY ENGINEERING AND CONTROL SEMIANNUAL PROGRESS REPORT NOVEMBER AND DECEMBER 1976 AND \\ JANUARY THROUGH APRIL 1977}

\section{SERVICE LABORATORIES GROUP}

Robert L. Carpenter

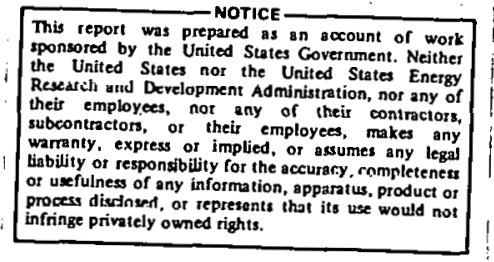

ROCKWELL INTERNATIONAL ATOMICS INTERNATIONAL DIVISION ROCKY FLATS PLANT

$$
\text { P.O. BOX } 464
$$

GOLDEN, CULÚRADO 80401

Prepared under Contract EY-76-C-04-3533 for the

Albuquerque Operations Office

U. S. Energy Research and Development Administration 


\section{SUB J E CT DES C R I P TOR S}

Absorption Spectroscopy

Adhesives

Alpha Spectroscopy

Arsenic

Asbestos

Atomic Absorption Spectroscopy

Calumimetry

Corrosion

Data Acquisition

Deposition

Differential Thermal Analysis

Electrolysis

Electrolytic Cells

Electron Microscopy

Emission Spectroscopy

Flunrimetry

Gallium

Gamma Spectroscopy

Gas Analysis

Gas Chromatography

HEPA Filters

Hydrogen Isotopes

Ion Exchange Materials
Infrared Spectroscopy

Liquid Chromatography

Liquid Scintillation

Mass Spectroscopy

Metalworking Fluids

Microscopy

Particle Slze Analysis

Photónicrograpliy

Pluțnniumm

Porosity

Quantitative Chemical Analysis

Radiometric Analysis

Scintillation Counters

Selenium

Spectrophotometers

Surface Properties

Surface Waters

Thermal Analysis

Uranium

Waste Processing

Water

X-ray Fluorescence Analysis 


\section{CONTENTS}

\section{ABSORPTION SPECTROSCOPY}

SPECTROPHOTOMETER MODIFICATION.

Use of a microprocessor-controlled spectrophotometer, adapted to replace a manuallyoperated instrument, has resulted in a threefold improvement of the precision of routine colorimetric gallium determinations.

\section{ATOMIC ABSORPTION SPECTROSCOPY}

ASBESTOS IN EXPERIMENTAL FILTER MEDIA $\ldots \ldots \ldots \ldots \ldots \ldots \ldots \ldots \ldots \ldots \ldots$

Iron contents of acid-dissolved samples of high-efficiency particulate air (HEPA) filter media are correlated to the percent crocidolite asbestos incorporated into the filters during their construction.

\section{ARSENIC AND SELENIUM IN NATURAL WATERS}

Conversion of arsenic and selenium to relatively nonvolatile arsenides and selenides in sample-treatment steps results in a flameless atomic absorption spectroscopic method that can detect as little as 10 parts per billion of these elements.

\section{CALORIMETRY}

CALORIMETER IMPROVEMENTS AND DATA ACQUISITION $\ldots \ldots \ldots \ldots \ldots \ldots \ldots \ldots \ldots$

Descriptions are given of work done to improve the efficiency and stability of existing calorimeters and of a proposed computer-controlled data-acquisition system for the new processing facillty.

\section{ELECTROLYSIS}

REMOVAL OF PLUTONIUM FROM PROCESS WASTE STREAMS $\ldots \ldots \ldots \ldots \ldots \ldots \ldots \ldots$

Ion-column effluents were reduced in plutonium concentrations by a factor of 10,000 ; and a stainless steel-platinum-wire electrode combination was demonstrated in recent electrolysis experiments.

Studies, performcd to clarify the mechanism of disinfection, indicated that contact with an electrode was not necessary to inactivate bacteria. 


\section{EMISSION SPECTROSCOPY}

PLASMA-SOURCE ANALYSIS OF TRACE METALS IN OILS $\ldots \ldots \ldots \ldots \ldots \ldots \ldots$

The simultaneous determination of up to 20 metallic impurities in oils can be accomplished rapidly and accurately in a technique that is not influenced by viscosity differences in the samples.

\section{FLUORIMETRY}

IMPROVED DETERMINATION OF URANIUM IN PLUTONIUM SAMPLES $\ldots \ldots \ldots \ldots \ldots \ldots .6$

Modifications to the procedure include a flux which enables lower fusion temperatures, and more sensitive instrumentation which results in a significant reduction in the size of samples.

\section{GAS CHROMATOGRAPHY}

HYDROGEN AND HYDROGEN DEUTERIDE IN DEUTERIUM $\ldots \ldots \ldots \ldots \ldots \ldots \ldots \ldots \ldots$

Through use of a gas chromatograph equipped with a helium-ionization detector, the sensitivity of an existing method for gases was improved sufficiently to allow a minimum detectable limit of less than 10 parts per million by volume.

\section{INFRARED SPECTROSCOPY}

ANALYSIS OF METHANOL SOLUTIONS FOR TRIBUTYL PHOSPHATE $\ldots \ldots \ldots \ldots \ldots \ldots$

Determination of percent concentrations of tributyl phosphate (TBP) in methanol is possible by evaporating the methanol, quantitatively transferring the TBP to carbon tetrachloride, and subsequently measuring the alkyl absorbance of the resultant solution.

CARBON TETRACHLORIDE IN PARAFFINIC MINERAL OIL $\ldots \ldots \ldots \ldots \ldots \ldots \ldots \ldots$

Three different analytical wavelengths were selected in order to determine carbon tetrachloride in oil samples over a wide concentration range.

A method, ideally suited for rapid quality control assessment of reagent-grade chloroform, involves the measurement of the carbon-oxygen absorption maxima of alcohols in the sample. 


\section{LIQUID CHROMATOGRAPHY}

DETECTION OF NITROSAMINE IN SYNTHETIC CUTTING FLUIDS $\ldots \ldots \ldots \ldots \ldots \ldots \ldots$

Described are the synthesis of N-nitrosodiethanolamine, a known animal carcinogen, and subsequent attempts at detection and separation from some commercially available metalworking fluids used at Rocky Flats.

\section{LIQUID SCINTILLATION COUNTING}

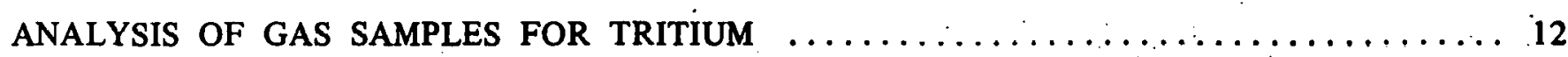

A minimum detectable amount of 2 micrograms per cubic metre of air is routinely attained in gas samples without their prior conversion to a liquid. The method is superior to previous analysis techniques.

\section{MASS SPECTROSCOPY}

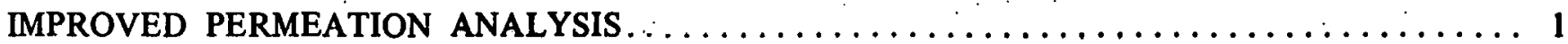

By the use of an argon internal standard and background-reduction techniques, the relative standard deviations of glove-port cover permeation-rate determinations were improved from a range of 60 to 70 percent to about 10 percent.

\section{MICROSCOPY}

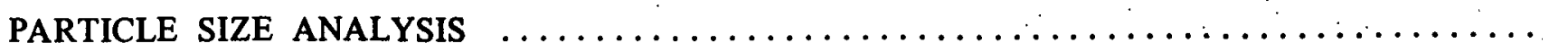

The Quantimet-720 apparatus, consisting of a group of individual modules that display, digitize, and analyze video data used in conjunction with a Reichert Microscope, furnishes a particle-size distribution of particulates in solution, as well as in powdered solids.

Abnormalities on plutonium metal surfaces are examined by photography, $\mathrm{X}$-ray fluorescence spectroscopy in conjunction with scanning electron microscopy, and electron diffraction analysis in conjunction with transmission electron microscopy.

INVESTIGATION OF DEPOSITED PLUTONIUM SURFACES $\ldots \ldots \ldots \ldots \ldots \ldots \ldots \ldots \ldots 16$

A goal for the safe nondestructive examination of metal surfaces was attained with the dcvclopment of a unique replication technique and subsequent instrumental manipulation of the replicated surface. 
Transmission electron microscopy coupled with selected area electron diffraction proved a viable method for identifying and counting asbestos minerals, specifically chrysotile and amphibole fibers.

POROSITIES OF WELD PHOTOMICROGRAPHS

Porosity measurements on photomicrographs of weld samples from batches of aluminum wire welds on beryllium form the basis of a quality-control test verification of the batches of wire.

\section{RADIOMETRIC ANALYSIS}

URANIUM-233 ANALYSES

The X-ray fluorescence, alpha-particle, and gamma-ray spectroscopic methods are applied to uranium-233 samples to determine assay, plutonium isotopes, and daughter products.

REVISED COMPUTER PROGRAM FOR DRUM COUNTING

Current computer software for the drum-counter system in the plutonium processing facility has been revised in order to simplify operations and speed data reduction without affecting the data-values output.

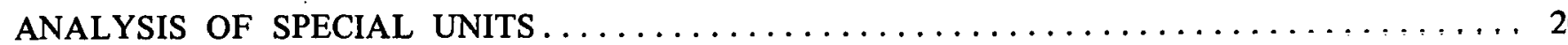

Gamma-ray spectroscopy is utilized to establish the metallic composition of routine site returns and to identify and quantitatively assess the fission products of special units that have been exposed to an off-site neutron source.

\section{THERMAL ANALYSIS}

IMPROVED SAMPLE LOADING FOR DIFFERENTIAL THERMAL ANALYSIS $\ldots \ldots \ldots \ldots .21$

Modification of the heating block assembly on a DuPont-900 Thermal Analyzer has shortened sample change time and simplified the loading operation by eliminating clumsy wire manipulations.

Differential thermal analysis and infrared spectroscopy were used to examine the thermal decomposition mechanism in a Dowex 1-X4 resin-acid system and to establish the oxidative nature of its initial exothermic reaction. 


\section{MISCELLANEOUS PROJECTS}

NONDESTRUCTIVE METHOD FOR GALLIUM IN PLUTONIUM $\ldots \ldots \ldots \ldots \ldots \ldots \ldots \ldots$

New equipment selected for the automated determination by an energy dispersive X-ray method and the improved results obtained are discussed.

TRACE CYANIDES IN NATURAL WATERS

A rapid method involving the use of a silver-sulfide specific-ion electrode provides about an order of magnitude more sensitivity toward cyanides than the conventional cyanide specific-ion electrode.

WATERBORNE EFFLUENT MONITORING

The annual revision has been completed for this program which summarizes Plant efforts to analyze and characterize various local water sources.

All analytical data generated on 43 hydrologic test holes for a 30 -month period have been edited and compiled into a 200-page booklet available for distribution.

\section{MONITORING OF ACID GASES THROUGH PARTICULATE AIR FILTERS}

Variations in the trace concentrations of hydrogen fluoride and total acids in pre-filter and post-filter air samples are summarized, and a mechanism for the interaction of acid gases with high-efficiency particulate air (HEPA) filters is presented.

Information has been provided to identify the composition of adhesives in high-efficiency particulate air (HEPA) filter media and to characterize their resistance to chemical attack, thermal properties, and flammability for quality acceptance tests. 


\title{
QUALITY ENGINEERING AND CONTROL SEMIANNUAL PROGRESS REPORT NOVEMBER AND DECEMBER 1976 AND JANUARY THROUGH APRIL 1977
}

\author{
SERVICE LABORATORIES GROUP
}

Robert L. Carpenter

\section{ABSORPTION SPECTROSCOPY}

\section{SPECTROPHOTOMETER MODIFICATION}

\section{Reuben J. Sironen and James A. Merriman}

\section{Summary:}

A microprocessor-controlled Beckman Model-24 Spectrophotometer with an automatic sample changer has been adapted to replace a manuallyoperated Beckman Model-DU Spectrophotometer used for the routine analysis of gallium. Due to the improvements in the precision of wavelength selection and absorbance measurements, an improvement factor of 3 in the precision of the method has been realized. A side benefit includes the ability to run more samples per unit of time with substantially less man power.

\section{Experimental:}

The Beckman Model-DU Spectrophotometer provided reliable service for many ycars, but the instrumenl required constant analyst involvement. As a result, the precision of the gallium analysis was dependent to a large extent on the analyst. To overcome this limitation, the Model-24 Spectrophotometer was purchased with an optional automatic sampling system for glove-box use.

The standard deviation for the gallium analysis averaged 0.020 with the previously used Model-DU spectrophotometer. After installation of the new spectrophotometer, the standard deviation was improved to 0.015. An additional increase in precision to 0.007 was obtained by changing the sample handling proccss. This change also simplified the operation and increased operator output. A microprocessor-based control system was designed and constructed to implement part of these changes. The problem with the initial sample-handling process was that the spectrophotometer and sample changer operated independently. As a result, when the logic sequence between the two systems lost synchronization, a loss in precision occurred. The new control system operates in a handshake mode so that each step of the process has to be acknowledged before the next step can occur. This system of control prevents the loss of synchronization.

The spectrophotometer and control system are connected to the SEL-840 MP laboratory computer and all data are calculated and statistically evaluated before the results are sent back to the analyst for release to the customer.

\section{ATOMIC ABSORPTION SPECTROSCOPY}

\author{
ASBESTOS IN \\ EXPERIMENTAL FILTER MEDIA \\ Clyde E. Michel, Keith J. Grossaint, \\ and Dana L. Portlock
}

\section{Summary:}

A procedure has been established for determining the crocidolite asbestos content of high-efficiency particulate air (HEPA) filter media. Standard atomic absorption techniques are employed on aciddissolved HEPA filter media samples to determine iron content, and these results are used to calculate the percent crocidolite asbestos employed in their construction. 


\section{Experimental:}

An asbestos fiber is added to HEPA filter media to impart favorable properties. The current specification for HEPA filter components is 5-weight percent asbestos in the glass-fiber medium. The asbestos mineral of choice is normally the amphibole, crocidolite. This mineral has properties, such as the nominal size of fibers (diameter and length), ease of dispersion, texture, and chemical resistance, which are more favorable than other asbestos minerals. Crocidolite is a sodium iron silicate with the approximate chemical composition, $\mathrm{Na}_{2} \mathrm{Fe}_{3} \mathrm{Fe}_{2} \mathrm{Si}_{8} \mathrm{O}_{22}(\mathrm{OH}, \mathrm{F})_{2}$, and a theoretical iron content of 29.84 weight percent.

An analytical procedure was developed to determine the asbestos content in HEPA filter media to maintain quality control standards in support of the HEPA-filter development program at Rocky Flats. The procedure involved direct determination of the iron content and subsequent calculation of the asbestos content. The standard atomic-absorption spectroscopic method for determining iron was chosen because it was rapid, accurate, and reliable. Limitations in the method related to problems of indirect measurement (knowledge of asbestos type actually used) and the possibility of contamination from other sources. In practice, the iron content of other constituents of the media was found to be insignificant.

In the procedure, samples are prepared by weighing between 0.1 and 0.2 grams of the HEPA filter media in a platinum crucible and subsequently dry-ashing at $400{ }^{\circ} \mathrm{C}$ to destroy any organic matter present. The residue from ashing, primarily crocidolite, glass fiber, and traces of other inorganic impurities, can then be dissolved in nitric acid and hydrofluoric acid. Heating the solution removes siliceous matter by volatilization as silicon tetrafluoride, and the remainder of the sample is dissolved in dilute nitric acid. The stock solution is then analyzed for iron by atomic absorption spectroscopy, which permits a relative accuracy of about \pm 5 . percent of the amount of iron present.

Typically, iron results of 30.5 weight percent were analy tically determined for crocidolite asbestos, which agreed well with the theoretical iron content. The high bias was attributed to actual differences from theoretical iron contents for the specific mineral asbestos, Blue African, used in the study.

\section{ARSENIC AND SELENIUM IN NATURAL WATERS}

\author{
Clyde E. Michel
}

\section{Summary:}

A rapid sensitive method has been developed for determining arsenic (As) and selenium (Se) in natural waters using flameless atomic absorption spectroscopy. By converting As and Se to relatively nonvolatile arsenides and selinides, respectively, in the sample treatment steps, a lower detection limit of 0.01 milligrams per litre $(\mathrm{mg} / \mathrm{l})$ is routinely attained.

\section{Experimental:}

Part of the Plant eftluent-monitoring program involves the routine analysis of pond waters for As and Se. The new method significantly reduces the analysis time by a factor of 5 as compared to the previously used methods and maintains approximately the same sensitivity and accuracy. Typical sample turnaround time for this method is 30 minutes. A major modification involves the formation of relatively nonvolatile nickel arsenide and nickel selenide by adding nickel nitrale solution to the water solution. Samples treated in this manner are then injected into the graphite furnace and analyzed by atomic absorption spectroscopy for either As or Se. Using the method of standard additions and pyroly tic-coated graphite tubes, a lower detection limit for both elements of $0.01 \mathrm{mg} / 1$ (about 10 parts per billion) has been attained for typical 50-microlitre sample aliquots.

\section{CALORIMETRY}

\section{CALORIMETER IMPROVEMENTS AND DATA ACQUISITION}

\section{Michael Smith}

\section{Summary:}

Described are efforts done to improve the efficiency and stability of the calorimeters in the 
Radiochemistry Laboratory. In addition information is given on the preliminary investigation of a computer-controlled data-acquisition system for the calorimeters to be employed in the new processing facility.

\section{Experimental:}

Calorimetry is a nondestrictive assay technique based on the determination of heat (wattage) emitted by a radionuclide. The heat from a sample is measured and compared either to a known amount of electrical heat (primary standard) or to a certified power standard such as plutonium 238 $\left({ }^{238} \mathrm{Pu}\right)$ (secondary standard). Wattage data, combined with known sample isotopic distribution, provide the basis for a quantitative method of determining the abundance of various nuclear materials.

Calorimetry has been in continued use for almost 15 years. Experiments began with a twin-cell calorimeter developed by Oetting to investigate the use of calorimetry in analyzing various samples of plutonium-bearing materials and in determining the half-lives of isotopes. ${ }^{1,2}$ Heavy sample load, including production samples, random samples of various types of plutonium-bearing materials, and americium samples prompted the design and construction of the present 3 eight-cell calorimeters. ${ }^{3}$

Relative precisions of 0.5 percent or better can be achieved with the present laboratory calorimetric system. This requires continuous maintenance and design improvement, such as the following: (1) To reduce axial heat loss in some calorimeters, the Styrofoam ${ }^{\circledR}$ insulators were replaced and new polyethylene lids installed. The cell-baselines in these units now exhibit greater stability; (2) The Lucite $($ cover on another calorimeter was removed and the open areas were covered with individually

\footnotetext{
'Franklin L. Oetting. "Determination of Plutonium in Plutonium Oxide by Calorimetry." Journal of Inorganic and Nuclear Chemistry 27:2151. October 1965.

${ }^{2}$ Franklin L. Oetting and Stuart R. Gunn. "A Calorimetric Determination of the Specific Power and Half-Life of Americium241." Journal of Inorganic and Nuclear Chemistry 29:2659. November 1967.

${ }^{3}$ Robert G. White and Frank L. Oetting. Private Communication. Rocky Flats Plant. March 1977.
}

fitted sections of stainless steel. This eliminated the excessively humid environment to which these cells were formerly exposed and resulted in their improved stability; (3) Cells in some calorimeters, which were damaged from water leaking into the corroded aluminum cell containers, were rewound, and a larger gauge wire was used, resulting in increased sensitivity. Also, all the cell containers in these units were replaced with ones made of brass pipe stock, which is more resistant to corrosion; (4) The ${ }^{238} \mathrm{Pu}$ heat standards were repackaged in stainless steel cans with 1 kilogram $(\mathrm{kg})$ of sea sand in order to simulate the heat transfer properties of plutonium dioxide. This procedure should greatly reduce heat-distribution error, ${ }^{4}$ since heat is now irradiating from a source with about the same size and heat distribution as a routine sample, instead of from a concentrated source such as the small sealed container of ${ }^{238} \mathrm{Pu}$.

Some problems with these calorimeters however still remain to be solved. The major one concerns the constant temperature bath, which lacks insulation between it and the room environment. The Hallikainen bath-temperature controllers have proved to be too slow in readjusting the preset temperature after fluctuations in the cooling-water temperature or the room temperature, which is not regulated. Another problem involves wiring from each cell to the switching box and digital volt meter (DVM). These wires are subjected to temperature and humidity changes in the room, which, if severe enough, can cause baseline fluctuations. Many of these problems have been considered and resolved in the design and construction of the calorimeters for the new processing facility. ${ }^{5}$ A major improvement in the design includes a ratio circuit which combines the reference cell, one of the sample cells, and the DVM into a single bridge circuit. In the present design, the bridge circuit, made from two resistance coils from each reference and sample cell, is separate from the DVM. Because of inherent differences built into the cells, this bridge is never in balance; thus, voltage fluctuations in either the

\footnotetext{
${ }^{4}$ Calibration Technique for the Calorimetric Assay of Plutonium. Bearing Solids Applied to Nuclear Materials Control. ANSI N1S.22. American National Standards Institute, Inc., New York. 1975.

${ }^{5}$ Ceorge P. Minges. Private Communication. Rocky Flats Plant. March 1977.
} 


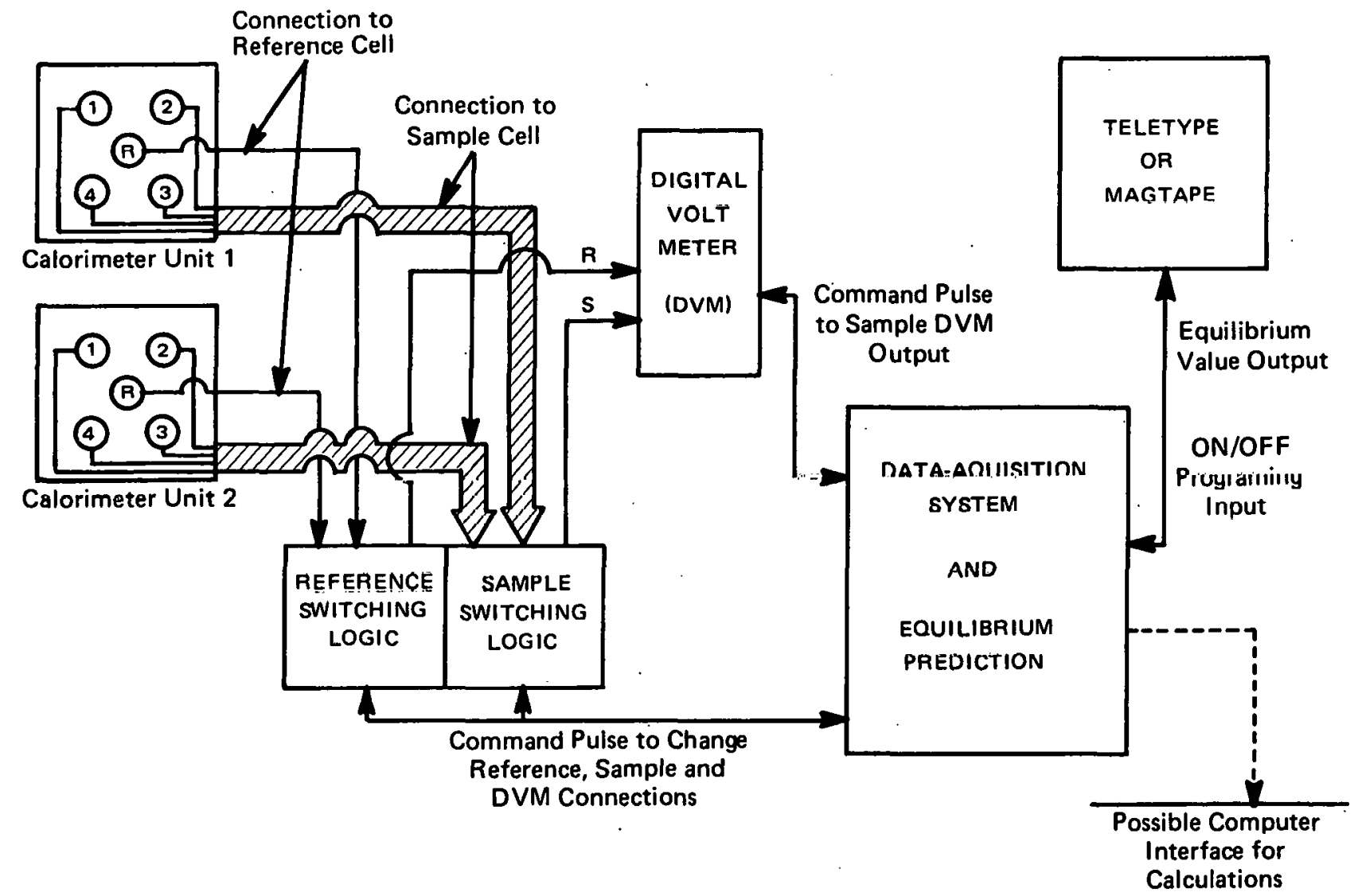

FIGURE 1. Block Diagram for Calorimeter Data-Acquisition System.

power supply or the DVM result in random baseline drift. By incorporating the DVM into the bridge, voltage fluctuations are cancelled out and the bridge remains balanced. ${ }^{6}$

It has become apparent that much experimental effort would be saved if an automatic dataacquisition system could be designed for use with the calorimeters. Such a system would also be extremely useful in the calibration of the instruments, since standards and blanks could be run more often. Preliminary work is under way on such a system. Prototypes of automatic logic-switching devices are being tested on the new calorimetry system being built for the Chemical Standards Laboratory. A more complex logic-switching device and a microcomputer for the prediction of equilibria are also being investigated.

Figure 1 depicts a block diagram of a data-acquisition system employing just two calorimeter units for simplicity. A sample cell and its reference cell are connected into a bridge circuit with the DVM by means of a switching circuit that uses logic flip-flops instead of mechanical rotary switches. Command pulses, which change the connections from cell to cell and from calorimeter to calorimeter, are provided by a hardwired control system. The time interval between switching is set to allow the control system to take the DVM reading, to compare it with the previous reading for that cell before going to the next cell, and, by curve fitting to make a prediction of the equilibrium reading. When an equilibrium value has been reached, this value is

\footnotetext{
'Ibid.
} 
then stored on tape or printed out on the teletype. If this data-acquisition system could be interfaced to a dedicated computer with a memory large enough to handle the calorimeter calculation program $(50,000$ to 100,000 words), the plutonium content of samples could be calculated as soon as the data were received. This would eliminate the manual transfer of acquired data to the computer as presently done.

\section{ELECTROLYSIS}

\section{REMOVAL OF PLUTONIUM FROM PROCESS WASTE STREAMS}

Jack L. Long

\section{Summary:}

Electrolysis experiments relating to the removal of plutonium $(\mathrm{Pu})$ from waste streams were continued. An ion-column effluent was reduced in $\mathrm{Pu}$ concentration by about a factor of $10^{4}$. An inexpensive combination of a stainless steel-platinum wire electrode was successfully used in place of the platinum-mesh electrodes previously employed in such experiments.

\section{Experimental:}

An ion-column effluent originating from the $\mathrm{Pu}$ processing facility was subjected to 4 stages of electrolysis. After each stage, the electrodes were leached with approximately 10 percent aqueous nitric acid containing 0.01 molar hydrofluoric acid to remove $\mathrm{Pu}$ and plutonium dioxide. Prior to each electrolysis stage, the solution was adjusted to a $\mathrm{pH}$ of 11 . The Pu concentration was reduced from $2.5 \times 10^{-5}$ to $2.9 \times 10^{-9}$ grams per litre $(\mathrm{g} / \mathrm{l})$, and the americium content was reduced from $2.1 \times 10^{-7}$ to $1.1 \times 10^{-9} \mathrm{~g} / 1$. Experiments involving leaching of the electrodes after an electrolysis trial have indicated that $\mathrm{Pu}$ is concentrated by a factor of 10 in the acid leach solution when compared to an equal volume of the remaining electrolyte. Further modifications to the system. should improve this ratio in future experiments.

Success was achieved in the substitution of a platinum anode wire of 1.0 millimetres ( $\mathrm{mm}$ ) in diameter and a stainless-steel cathode for the platinum-mesh electrodes used in prior electrolysis experiments. The stainless steel-platinum wire combination would allow a substantial savings in capital costs on a large-scale electrolytic cell unit.

\section{ELECTROLYTIC DISINFECTION OF SEWAGE}

\author{
Jack L. Long and Nolan E. Moody
}

\section{Summary:}

Electrolysis investigations were continued to clarify the mechanism of bacterial disinfection. Microscopic observation showed that clumping of bacteria resulted from electrolysis, and bacterial movement decreased as the time of electrolysis increased. A 3-compartment cell indicated contact with an electrode was not necessary to inactivate bacteria.

\section{Experimental:}

A cell for microscopic examination of bacteria was constructed so that observations could be made at a magnification factor of 400 during electrolysis. It was necessary to add nutrient and bacteria cultures to ordinary sewage because the concentration of bacteria was less than one per field of view with ordinary secondary sewage from the Rocky Flats facility. Since natural sewage always contains chloride ion which forms chlorine during electrolysis, a synthetic sewage was prepared by adding nutrient. and bacteria cultures to distilled water. This synthetic sewage experiment was necessary to show that bacteria inactivation was not caused by chlorine disinfection. Repeated observations with both kinds of sewage indicated that microrganisms tend to clump together when electrolyzed and that bacterial movement lessens as the time of electrolysis is increased.

To demonstrate that electrode contact was not necessary for bacterial inactivation, a 3-compartment cell was constructed by using a cation-excharge membrane and an anion-exchange membrane sealed in a plastic framework. The membranes prevented the flow of liquids between compartments, but cations could traverse the anion exchange membrane. A decrease by orders of magnitude in bacteria as measured by dip testers was observed in the middle 
compartment. Since no chlorine was detected in this compartment and it was assumed that bacteria did not pass through the membranes, the conclusion was that bacteria were destroyed by some chargetransfer process in the center cell. The membranes alone had no effect on the disinfection process. Experiments performed without current flow indicated no changes in bacteria concentration.

\section{EMISSION SPECTROSCOPY}

\section{PLASMA-SOURCE ANALYSIS OF TRACE METALS IN OIL}

\author{
Ann C. Ficklin
}

\section{Summary:}

The simultaneous determination of up to 20 metallic impurities in oil can be accomplished rapidly and accurately with use of a plasma-source emission spectrometer. This technique is not influenced by viscosity differences in oils which bias the more traditional emission spectrometry determinations.

\section{Experimental:}

Wear metals and soil elements (such as boron and silicon) traditionally have been determined in lubricating oils by emission spectrometry techniques. Recent evidence indicates a significant bias exists in results obtained on samples whose viscosities differ from those of oil standards. Atomic absorption spectroscopy, a reliable alternate method, suffers from the limitation of determining only a single element at a time. Problems were overcome with the Spectraspan-III Plasma Jet spectrometer. Routinely, 11 elements (tin, chromium, nickel, boron, silicon, iron, copper, silver, lead, aluminum, and beryllium) are determined simultaneously on a single oil sample; however, up to 20 elements may be run simultaneously on the spectrometer.

In this technique, sample oils and oil standards are first diluted by half with Stoddard solvent (Exxon Varsol®) to sufficiently reduce their viscosities and to permit efficient pumping into the plasma-jet source. The standard oils employed in this investigation are the Conostan $\otimes$ D-20 series. The blank oil is metal-free Regal A-R\&O Hydraulic Oil
TABLE I. Plasma-Jet Emission Spectrometric Determination of Trace Metals in Standard Reference Fuel Oil.

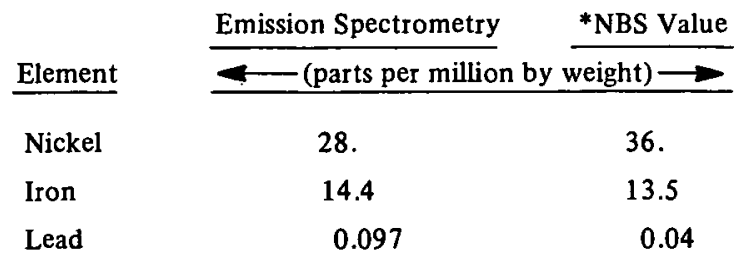

*National Bureau of Standards, Washington, D.C.

diluted by half with Stoddard solvent: Three machine oils of varying viscosities were spiked with Conostan-D standards and analyzed. The results indicated that variations in the viscosities have no signilicanl ellect on the emission spectrometric determination of metals in the oils. A National Bureau of Standards (NBS) Reference Fuel Oil, SMR 1634, wás ảnàlyzzed to assess the accuracy of the method, and the results are summarized in Table I. Results from the atomic absorption analyses of seven different oils from various metals were compared with results from the plasma-jet emission spectrometry determinations, and the agreement between the two methods was within 20 relative percent.

\section{FLUORIMETRY}

\section{IMPROVED DETERMINATION OF URANIUM IN PLUTONIUM SAMPLES}

Donald P. Anderson and Harold L. Wells

\section{Summary:}

The procedure to determithe microgram amounts of uranium (U) in plutonium metal, liquid, and oxide samples was modified to enable fusions at temperatures of less than $750^{\circ} \mathrm{C}$. In addition, the Jarrell-Ash Fluorometer was replaced with a more sensitive Turner Fluorometer which allowed the size of samples to be reduced from 250 to 50 milligrams. This sample reduction resulted in the generation of less plutonium wastes for reprocessing as well as the elimination of quenching because of impurities. 


\section{Experimental:}

Previously, individual sample aliquots were fused at temperatures above $750^{\circ} \mathrm{C}$ with a Bunsen burner and flux consisting of lithium and sodium fluoride. The consequence of high fusion temperature was nonreproducibility of $U$ results because of quenching of $U$ fluorescence by platinum from the fusion vessel. ${ }^{7}$.It became desirable to fuse all the sample aliquots at one time in an electric furnace at a temperature of less than $750^{\circ} \mathrm{C}$ for speed and reproducibility. A flux composed of 45.5 parts sodium carbonate, 45.5 parts percent potassium carbonate, and 4.5 parts sodium fluoride resulted in a satisfactory fusion at $650^{\circ} \mathrm{C}$ in a time of 25 minutes.

The use of this carbonate-fluoride flux caused another problem. A strong reaction occurred between the basic flux and the acid solution of the samples when pipetting the small aliquot ( 50 microlitres) onto the flux pellet. This problem was solved by reducing the acid concentration of the sample solution by adding 5 millilitres of 2 molar sodium hydroxide solution instead of 5 millilitres of water as was done previously. Since interferences in fluorimetry are proportional to the quantities of the interfering elements and not to the ratio of uranium to interfering elements, interferences are practically eliminated by the reduction in aliquot size. These modifications to the method reduce the analysis time in half. The relative standard deviation of this method is \pm 7 percent.

\section{GAS CHROMATOGRAPHY}

\section{HYDROGEN AND HYDROGEN DEUTERIDE IN DEUTERIUM}

\author{
Virgil H. Matzick
}

\section{Summary:}

The sensitivity of an existing method for detcrmining hydrogen $\left(\mathrm{H}_{2}\right)$ and hydrogen deuteride (HD) in deuterium $\left(D_{2}\right)$ was improved through use of a gas chromatograph equipped with a helium-ionization

\footnotetext{
${ }^{7}$ Marc H. Fletcher. "A Study of Critical Factors in the Direct Fluorimetric Determination of Uranium." U.S. Geological Survey Bulletin 1006:51. 1954.
}

detector. Minimum detectable limits for these gases were improved to less than 10 parts per million (ppm) by volume.

\section{Experimental:}

The gas chromatographic method for chromatograph instruments equipped with thermal conductivity detectors was adapted recently. ${ }^{8,9,10}$ In order to effect separation of the gases under study, a 12-foot column of stainless steel, packed with activated alumina, had to be immersed in liquid nitrogen.

The HD needed for standards was prepared in a Parr oxygen bomb by equilibrating equal volumes of $\mathrm{H}_{2}$ and $\mathrm{D}_{2}$ over a hot Nichrome ${ }^{8}$ wire. A series of $\mathrm{HD}$ standards was made by diluting the resultant reaction mixture with helium gas. The principal standard employed in the quality control analysis of incoming cylinders of $\mathrm{D}_{2}$ contained $486 \mathrm{ppm}$ HD. The initial $D_{2}$ samples analyzed by this method contained between 4- and 5-volume percent HD but less than $10 \mathrm{ppm} \mathrm{H}_{2}$. This gas chromatographic method has a minimum detectable limit of less than $10 \mathrm{ppm}$ for $\mathrm{H}_{2}, \mathrm{HD}$, and $\mathrm{D}_{2}$. Consequently, HD can be determined with more sensitivity by this method than by mass spectroscopy which is accurate for percentage concentrations.

\section{INFRARED SPECTROSCOPY}

\section{ANALYSIS OF METHANOL SOLUTIONS FOR TRIBUTYL PHOSPHATE \\ Patricia A. Hyman}

\section{Summary:}

Using infrared spectroscopy, indirect measurements can be made of the volume percent tributyl

\footnotetext{
${ }^{8}$ P. G. Jeffery and P. J. Kipping. Gas Analysis by Gas Chromatography. The MacMillan Company, New York. 1964. Pages 95-101.

A. B. Littlewood. Gas Chromatography. Second Edition. Academic Press, New York and London. 1970. Pages 427-429.

${ }^{10}$ Claude Genty and Robert Schott. "Quantitative Analysis for the Isotopes of Hydrogen- $\mathrm{H}_{2}, \mathrm{HD}, \mathrm{HT}, \mathrm{D}_{2}, \mathrm{DT}$, and $\mathrm{T}_{2}-$ by Gas Chromatography." Analytical Chemistry 42:7. January 1970.
} 


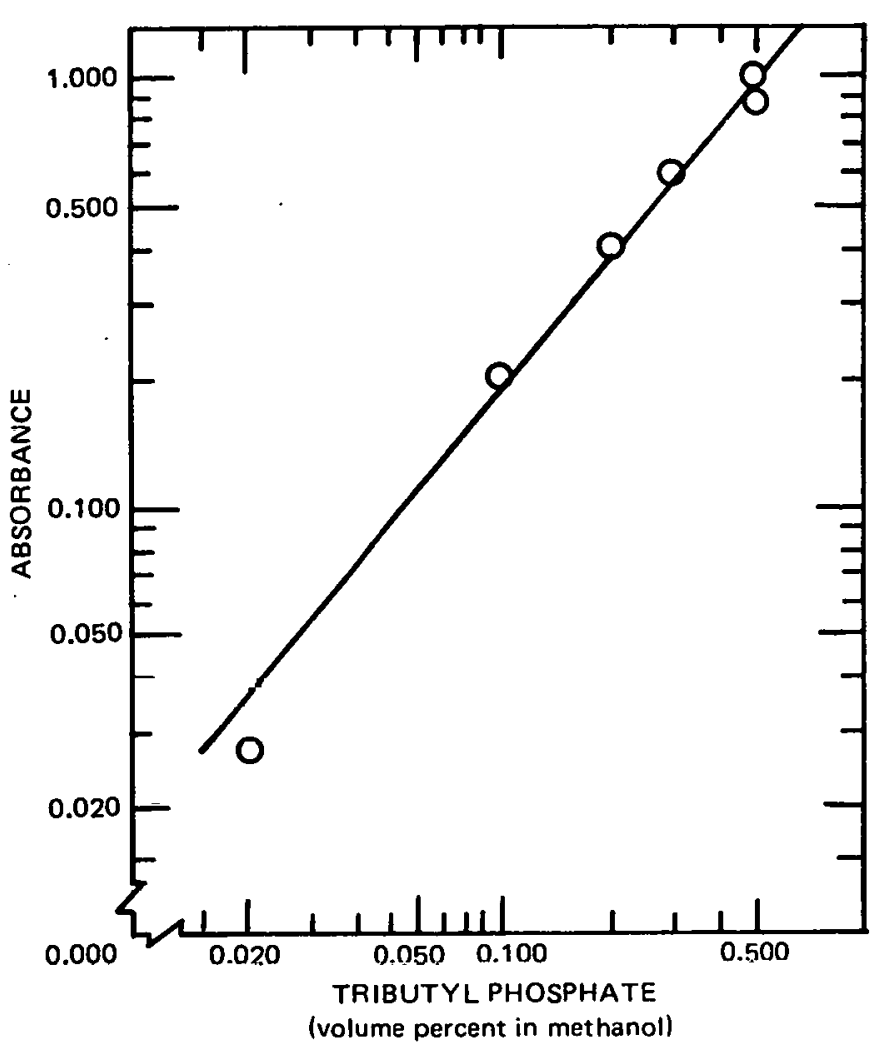

FIGURE 2. Beer-Lambert Calibration Plot for Tributyl Phosphate in Methanol.

phosphate (TBP) in methanol solutions. As methanol has an intense infrared spectrum, obscurring that of TBP, the methanol must first be separated from the TBP via evaporation (TBP is not volatile). The TBP residue is then quantitatively dissolved in carbon tetrachloride $\left(\mathrm{CCl}_{4}\right)$, and volume percent TBP is determined by measuring the alkyl (C-H) absorbance of the TBP.

\section{Experimental:}

Standard solutions of TBP in methanol in the concentration range of 0.02 to 0.50 volume percent were prepared. The methanol was evaporated from a known volume of each standard and the residual TBP was quantitatively transferred with $\mathrm{CCl}_{4}$ to a 5-centimetre path-length glass cell with sodium chloride windows. The $\mathrm{C}-\mathrm{H}$ absorbance at 3.4 micrometres $(\mu \mathrm{m})$ was measured differentially against $\mathrm{CCl}_{4}$ in a matched reference cell using the baseline method. A standard Beer-Lambert plot of absorbance at $3.4 \mu \mathrm{m}$ versus percent TBP in the standard methanol solution was prepared and found to be linear over the concentration range of 0.02 to 0.50 volume percent. A typical Beer-Lambert calibration plot is given in Figure 2. By varying the volume of the initial sample to be evaporated (e.g., 1.0 to 10.0 millilitres), this method can be made applicable over a wide concentration range (i.e., 0.002 to 0.5 volume percent). The reproducibility of the standard determinations is \pm 10 percent. No recovery factor is needed for this method since the samples are analyzed in exactly the same manner as the standards.

\section{CARBON TETRACHLORIDE IN I'ARAIIIINIC MINERAL OIL}

\author{
Roger S. Cichorz
}

\section{Summary :}

The concentration of carbon tetrachloride $\left(\mathrm{CCl}_{4}\right)$ in paraffinic base mineral oils can be rapidly and accurately determined by infrared spectroscopy: The range of concentrations of $\mathrm{CCl}_{4}$ in oil samples housed in a 0.10 -millimetre path-length cavity cell is dependent on the analytical absorption maximum chosen. In this investigation, three analytical wavelengths reflecting different absorption maxima were selected to allow for the detection of less than 0.015 volume percent $\mathrm{CCl}_{4}$ to as high as 25 volume percent $\mathrm{CCl}_{4}$.

\section{Experimental:}

During the course of investigation of the recovery of $\mathrm{CCl}_{4}$ from spent plutonium-machining coolant (mixtures of $\mathrm{CCl}_{4}$ and paraffinic base hydraulic oils), a rapid method was needed for determining the $\mathrm{CCl}_{4}$ contents of the distillation residues. Infrared spectroscopy was a logical choice since it is amenable to the examination of organic compounds and a proven quantitative technique for determining mixtures. Futhermore, the plutonium-contaminated samples could be handled easily and safely once totally contained within the stoppered cavity cells used to record infrared spectra.

The infrared spectra of paraffinic base mineral oils and $\mathrm{CCl}_{4}$ are sufficiently different. Thus in the spectra of oil- $\mathrm{CCl}_{4}$ mixtures, the contributions of each constituent are readily separable from one another with a minimum of interference, and a 
TABLE II. Summary of Beer-Lambert Data for Carbon Tetrachloride in Paraffinic Base Mineral Oil.

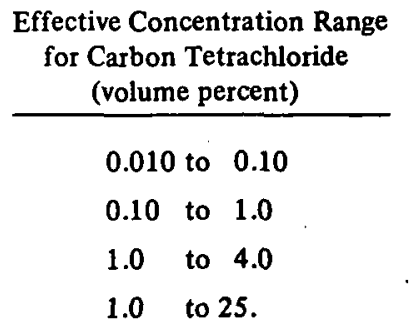

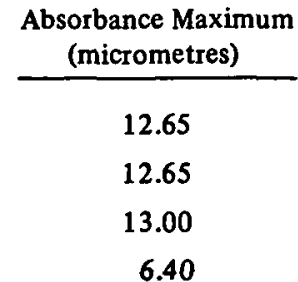

\begin{tabular}{c}
$\begin{array}{c}\text { Empirical-Ratio Reference Minimum } \\
\text { (micrometres) }\end{array}$ \\
\hline 14.55 \\
14.55 \\
14.55 \\
5.15
\end{tabular}

choice of analytical wavelengths for quantitation are available. Most of the spent coolant mixtures submitted for analysis contain between 10 and 20 volume percent $\mathrm{CCl}_{4}$, and the oils remaining after distillation generally contain only 0.1 to 1.0 volume percent $\mathrm{CCl}_{4}$. Consequently, several analytical absorption maxima of $\mathrm{CCl}_{4}$ had to be selected to prepare Beer-Lambert calibration plots which would allow for these relatively large ranges of $\mathrm{CCl}_{4}$ concentrations.

Standard solutions were prepared by introducing known volumes of $\mathrm{CCl}_{4}$ into a reference paraftinic base mineral oil (Texaco Regal A-R\&O Hydraulic Oil). The standards encompassed a range of $\mathrm{CCl}_{4}$ concentration over 4 orders of magnitude, starting at the minimum detectable limit of 0.010 volume percent up to a maximum of 25 volume percent.

The infrared spectra of the standard solutions were recorded in linear wavelength units [i.e., micrometres $(\mu \mathrm{m})]$ on a commercial prism-monochromator instrument against air under the normal operating parameters conducive to quantitative infrared determinations. The absorbance maxima chosen for the various concentration ranges of $\mathrm{CCl}_{4}$ in oil are summarized in Table II. Absorbance readings were measured by the empirical-ratio method, which involves subtraction of a neighboring absorption minimum from the analytical absorption maximum, rather than the standard baseline method. This was necessary to minimize changes in the slope of the baseline induced by differing $\mathrm{CCl}_{4}$-to-oil ratios.

For this method, reproducibilities of the abscissa (wavelength) maxima are not critical since the complete spectra are recorded rather than absolute absorbance determinations made at a given wavelength. The precision of the method is governed by the ordinate reproducibility of the instrument, which is less than 2 relative percent at the optimum absorbance range. With careful preparation of standards and periodic recalibrations, the method permits a relative accuracy of better than 5 relative percent over the entire concentration range examined. Total analysis time, which includes transferring the sample to the cell, recording the spectrum, emptying and cleaning the cell, and making the appropriate calculations, is about 30 minutes per sample.

\section{METHANOL AND ETHANOL IN CHLOROFORM}

\author{
Roger S. Cichorz and Reuben J. Sironen
}

Summary:

Infrared spectroscopy can be used to directly measure the volume percent of methanol and ethanol in chloroform. Methanol is determined by measuring its carbon-oxygen $\left(\nu_{\mathrm{C}-\mathrm{O}}\right)$ absorption maximum at 9.83 micrometres $(\mu \mathrm{m})$, and ethanol is determined by measuring its $\nu_{\mathrm{c}-\mathrm{O}}$ absorption maximum at $9.60 \mu \mathrm{m}$.

\section{Experimental:}

Standard solutions of chloroform containing methanol in the concentration range of 0.05 to 2.5 volume percent were prepared, and the infrared absorption at $9.83 \mu \mathrm{m}$ of each standard was measured by the baseline method. The standards were contained in a sodium chloride cavity cell with a fixed path length of 0.10 millimetres, and the absorption maximum was measured against air. 
FIGURE 3. Beer-Lambert Calibration Plots for Determining Concentrations of Methanol and Ethanol in Chloroform.

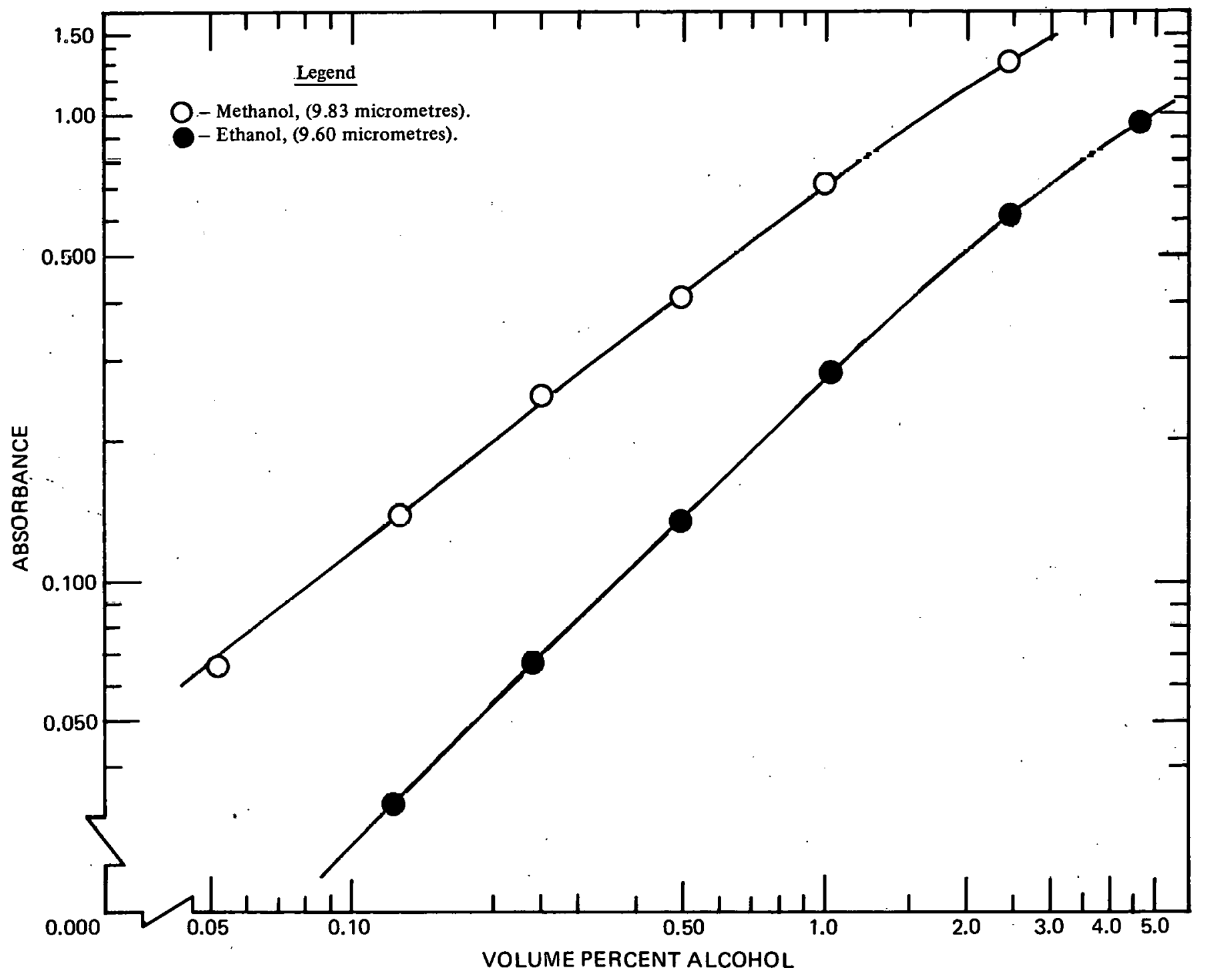


Chloroform contributes a slight absorbance at the analytical wavelength, but this was determined from an alcohol-free chloroform blank and subtracted from each absorbance reading. A Beer-Lambert plot of absorbance at $9.83 \mu \mathrm{m}$ versus percent methanol is linear over the concentration range of 0.05 to 1.0 volume percent, although the upper concentration detectable by this method approaches 3 percent. Since the samples are analyzed in the same manner as the standards, no recovery factor is necessary. For chloroform samples exceeding 3 percent methanol, appropriate quantitative dilutions with alcohol-free chloroform can be made, and the Beer-Lambert calibration plot can be applied to the samples.

Standard solutions of chloroform containing ethanol in the concentration range of 0.10 to 5.0 volume percent were similarly prepared, and the infrared absorption at $9.60 \mu \mathrm{m}$ of each standard was measured by the baseline method. Chloroform has no interfering absorption at this analytical wavelength, so no blank corrections are necessary in the ethanol determination. The Beer-Lambert plot of absorbance at $9.60 \mu \mathrm{m}$ versus percent ethanol is linear over the concentration range of 0.10 to 1.5 volume percent, although the upper concentration detectable by this method exceeds 5 percent. For chloroform samples exceeding 5 percent ethanol, quantitative dilutions with alcohol-free chloroform can be made and the Beer-Lambert calibration plot applied. Typical Beer-Lambert calibration plots are given in Figure 3.

The anticipated accuracy for the infrared spectroscopy method is better than 5 relative percent throughout the analytical range. For example, for a series of 4 chloroform standards containing 0.99 volume percent ethanol, the mean absorbance was determined to be $0.284 \pm 0.017$ at the 95 percent confidence level; the relative standard deviation was 3.0 percent. The method is also rapid. The procedure for loading the cell, recording the infrared spectrum, measuring the absorbance, and calculating the alcohol content takes less than 5 minutes. This method was developed at Rocky Flats specifically to monitor the ethanol and methanol concentrations of recycled chloroform distilled from the chloroform extract of the gallium (Ga)-oxine complex produced during spectrophotometric $\mathrm{Ga}$ determinations.
Since the color-developing reagent is prepared in methanol or ethanol, some alcohol is distilled over in the chloroform fraction. Furthermore, reagentgrade chloroform contains approximately 0.75 percent ethanol as an inhibitor against decomposition; consequently, the method is ideally suited for rapid quality control assessments of incoming reagent-grade chloroform.

\section{LIQUID CHROMATOGRAPHY}

\section{DETECTION OF NITROSAMINE IN SYNTHETIC CUTTING FLUIDS}

\author{
Mary L. Grooms
}

\section{Summary:}

The synthesis of N-nitrosodiethanolamine (NDElA) has been achieved, and water standards containing as little as 10 nanograms NDElA have been separated and detected by liquid chromatographic techniques. Some commercially available synthetic cutting fluids have been found to contain NDElA which causes liver tumors in rats. However in the present investigations at Rocky Flats, the NDElA has not been separated from other components in cutting fluids.

\section{Experimental:}

Synthetic cutting fluids are widely used at Rocky Flats in various machining operations. Several of these cutting fluid concentrates contain up to 45 percent triethanolamine and up to 20 percent alkali (sodium or potassium) nitrite. These two components may react under certain conditions to form NDElA $^{11}$ which has been shown to produce liver tumors in rats ${ }^{12}$ and is of interest. Any effect on humans however has not been established. ${ }^{13}$

\footnotetext{
"William Lijinsky et al. Journal of the National Cancer Institute 49:1239. November 1972.

${ }^{12}$ Hermann Druckery et al. Zeitschrift Fur Krebsforschung (Periodical of Cancer Research) 69:103. March 1967.

${ }^{13}$ Tsai Y. Fan et al. "N-Nitrosodiethanolamine in Synthetic Cutting Fluids: A Part-Per-Hundred Impurity." Science 196:70. April 1, 1977.
} 
The NDElA was prepared according to a procedure obtained from T. Y. Fan. ${ }^{14}$ Diethanolamine, sodium nitrite, and enough $2 \mathrm{~N}$ sulfuric acid to adjust the solution to a $\mathrm{pH}$ of 3.0 to 3.5 were mixed and allowed to stand overnight. Excess sodium nitrite was precipitated with isopropanol, filtered, and discarded, and the concentrated solution was cleaned on silica gel. A standard of NDElA in water was injected into a Model-6000A Liquid Chromatograph, equipped with a $\mu$-Bondapak- $\mathrm{C}_{18}$ column, using a solvent system of 50-percent acetonitrile and 50percent water, and a flow rate of 1 millilitre per minute. The lower detection limit of the ultraviolet detection at 254 nanometres for NDElA was 10 nanograms. The separation of NDElA from other components in the cutting fluids examined has not been achieved. A change in column or solvent system or both may be necessary to obtain the separation. Such separation would allow for the quantitative determination of NDEIA in the synthetic cutting fluids used at Roçky Flats.

\section{LIQUID SCINTILLATION COUNTING}

\section{ANALYSIS OF GAS SAMPLES FOR TRITIUM}

Duane I. Hunter and Terry F. Rees

\section{Summary:}

A new and superior method has been developed for analyzing gas samples by liquid scintillation counting (LSC) techniques without converting the gas to a liquid. Less than 7.5 millilitres of gas at standard temperature and pressure (STP) give a minimum detectable amount of 2 microcuries per cubic metre $\left(\mu \mathrm{Ci} / \mathrm{m}^{3}\right)$.

Tritium determinations of gaseous samples have been performed previously at Rocky Flats by using an internal gas-ionization chamber (Triton Analyzer)

\footnotetext{
${ }^{14}$ Tsai Y. Fan. Private Communication. Thermal Electron Cancer Research Center, Waltham, Massachusetts. February 1977.
}

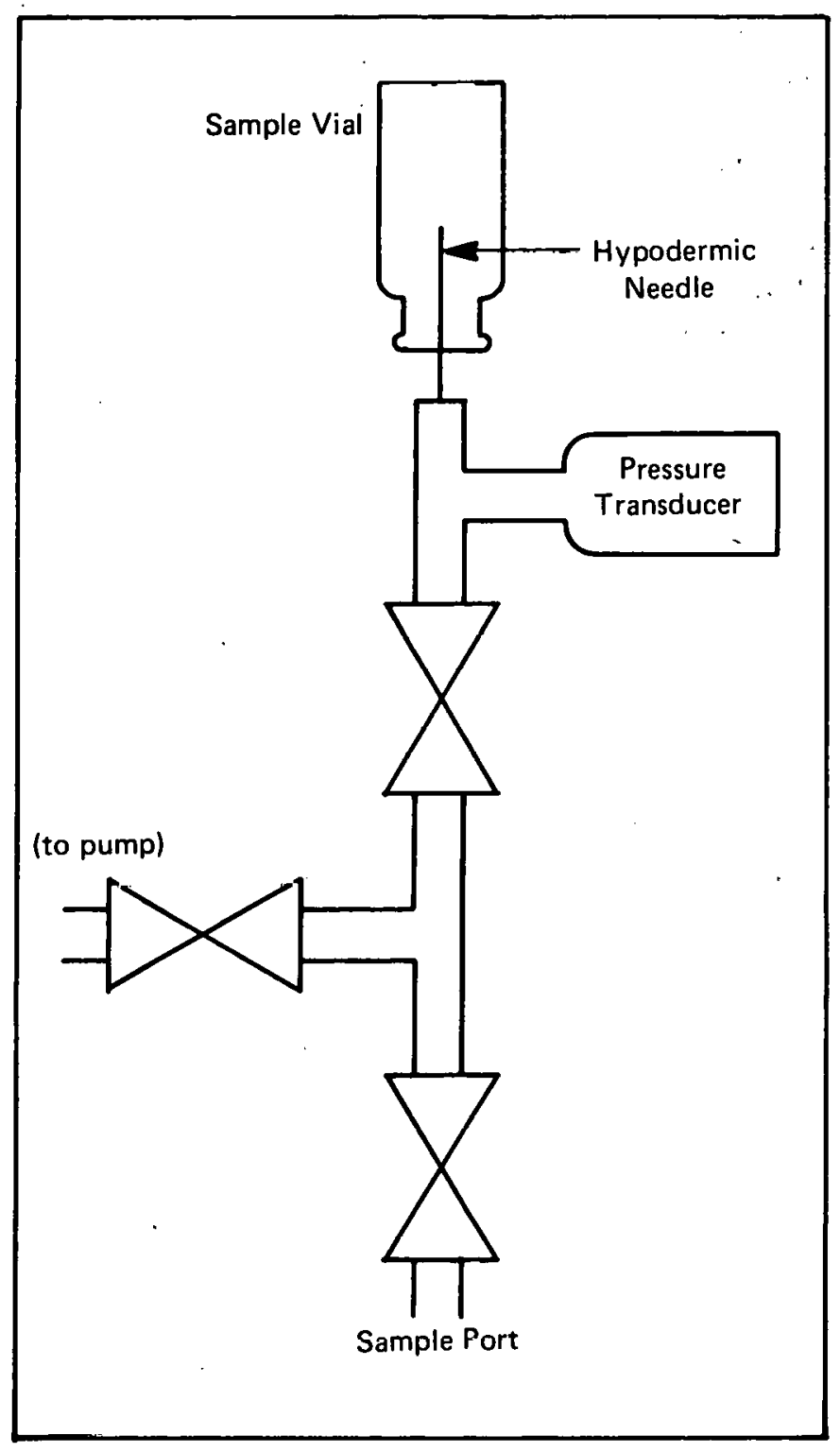

FIGURE 4. Sampling Manifold tor Tritium Gas Analysis.

or by converting the gaseous tritium to a liquid which could then be scintillation-counted. Both methods require sampling a large volume of gas and do not work well on static samples as large as 10 litres. The Triton-type counting is not specific for tritium, will not operate using a noble gas atmosphere, and is affected by gamma radiation. The conversion of gas to liquid (combustion to water) is comparatively complex and time-consuming for routine quantitative assay. 


\section{Experimental:}

A liquid-scintillation vial fitted with a rubber septum is placed on a hypodermic needle attached to a vacuum manifold (Figure 4). The sample gas is expanded into the evacuated vial, and the pressure measured using 0-to-750 torr transducer. The final vial pressure must be less than 250 torr $(1$ torr $=$ 133 pascals). After removing the vial from the manifold, a premixed scintillation cocktail is added through a hypodermic syringe with the plunger removed. The pressure inside the vial is returned to ambient by allowing the cocktail level in the syringe to stablize. The needle is then removed and the vial shaken to mix the contents.

Using helium as the fill gas, a background sample is prepared by the same procedure. The background, standards, and samples are counted using normal LSC techniques. The disintegrations per minute per vial pressure-volume data are converted to radiations per unit volume $\left(\mu \mathrm{Ci} / \mathrm{m}^{3}\right.$ at STP). If the volume and pressure of the original container or system are known or can be measured, the total quantity (in curies) of tritium can be calculated. Recoveries of standard tritiated methane in the concentration range of 2 to $>15 \mu \mathrm{Ci} / \mathrm{m}^{3}$ were better than 80 percent for all concentrations. Using a vial pressure of 250 torr ( 1 torr $=133$ pascals), the lower detection limit is $2 \mu \mathrm{Ci} / \mathrm{m}^{3}$. At lower pressures the detection limits become higher.

Several advantages of the LSC method are apparent: (1) the gas sample remains confined inside a sealed container throughout the analysis, (2) the total sampling and analysis time is only 15 minutes, and (3) the method is specific for tritium because of the preset energy discrimination windows in the scintillation counter.

\section{MASS SPECTROSCOPY}

\section{IMPROVED PERMEATION ANALYSIS}

Tom L. McFeeters

\section{Summary:}

Improved precision of permeation rate determinations by mass spectroscopy was accomplished by use of an argon internal standard and backgroundreduction techniques. The overall effect of the improvements was to reduce the relative standard deviation of glove-port cover permeation studies from a range of 60 to 70 percent to about 10 percent.

\section{Experimental:}

Permeability constants involve a factor (which normalizes area and sample thickness) and generally represent characteristics of the material and permeant. The actual quantity of permeant penetrating a sample, and also available for dynamic mass spectrometric measurement, is inversely proportional to sample thickness. Initial attempts to determine permeation rates for relatively thick glove-port covers resulted in poor precision (relative standard deviations were as high as 60 to 70 percent).

The poor reproducibility was caused by measurement of flow rates about 2 orders of magnitude lower than measurement on thinner samples. Thicker samples also required longer equilibration times to reach stable permeation rates after pressure changes. This allows more time for background and instrumental variations to occur between determinations.

Improved precision on permeation-rate data was obtained on the thick glove-port cover samples by use of an argon internal standard and by reduction of background variation. Representative data are given in Table III. An argon internal leak was attached to a permeation manifold, and the peak height of the argon internal standard measured when the instrument was calibrated for permeant sensitivity.

Prior to each subsequent background and permeation rate analysis, the argon peak height was adjusted electronically to the exact same peak-height value. This effectively eliminated instrumental variations between the series of analyses required for determination of a permeability constant. Background variation was reduced by taking instrument and manifold background scans immediately before and after each permeation-rate analysis. The overall effect of these changes was to improve the relative 
TABLE III. Glove-Port Cover Permeation Rates.

\begin{tabular}{|c|c|c|c|c|}
\hline \multirow{2}{*}{$\begin{array}{l}\text { Sample: } \quad \text { B } \\
\text { Thickness: a } \\
\text { Permeant Gas }\end{array}$} & \multicolumn{2}{|c|}{$\begin{array}{l}\text { Butyl Port Cover } \\
a_{123} \text { mils }\end{array}$} & \multirow{2}{*}{\multicolumn{2}{|c|}{$\begin{array}{l}\text { Sample: Chlorinated Polyethylene Port Cover } \\
\text { Thickness: }{ }^{a} 92 \text { mils } \\
\mathrm{b}_{\text {Mean Permeation Rate }} \\
\left(\begin{array}{c}\text { moles per torr- } \\
\text { second-centimetre }\end{array}\right)\end{array}$}} \\
\hline & $\begin{array}{c}\mathrm{b}_{\text {Mean Permeation Rate }} \\
\left(\begin{array}{c}\text { moles per torr- } \\
\text { second-centimetre }\end{array}\right)\end{array}$ & $\begin{array}{c}\text { Unbiased Relative } \\
\text { Standard Deviation } \\
\text { (percent) }\end{array}$ & & \\
\hline Hydrogen & $1.25 \times 10^{-14}$ & 12. & $2.14 \times 10^{-14}$ & 9.3 \\
\hline Nitrogen & $1.19 \times 10^{-15}$ & 27. & $1.46 \times 10^{-15}$ & 16. \\
\hline Oxygen & $5.48 \times 10^{-16}$ & 16. & $4.24 \times 10^{-15}$ & 7.4 \\
\hline Argon & $2.25 \times 10^{-16}$ & 4.9 & $3.92 \times 10^{-15}$ & 6.9 \\
\hline Carbon Dioxide & $5.43 \times 10^{-15}$ & 2.5 & $6.84 \times 10^{-14}$ & 16. \\
\hline
\end{tabular}

standard deviation from a range of 60 to 70 percent to about 10 percent.

\section{MICROSCOPY}

\section{PARTTICLE SIZE ANALYSIS}

\author{
John K. Fraser
}

\section{Summary:}

Powdered solids and particulates in solution, including radloactive materials, are analyzed for particle size distribution using a Reichert Microscope and the Quantimet-720 Analyzer. The particulates may range in size from a few tenths of a micrometre $(\mu \mathrm{m})$ to several hundred $\mu \mathrm{m}$ and be submitted in dry form or in liquid solution. Video images from a microscope slide containing the sample are transmitted to the analyzer and converted into various digital information including area, perimeter, intercept, and counting of the particles. Data from the analyzer are recorded on teletype paper tape and then reduced to reportable form using a Nuclear Data 8812 Computer.

\section{Experimental:}

Dry particulate samples are prepared by placing a small amount of the sample into immersion oil on a clean microscope slide. The sample is then evenly dispersed in the oil and covered with a cover slide. Radioactive liquid solutions containing particulates are filtered by use of a Millipore $\otimes$ microanalysis filter system. General application filters having a pore size of less than $0.1 \mu \mathrm{m}$ may be used in most cases. Strong acid or alkaline solutions need to be diluted to less than 6 normal if the general application filters are used. A small amount of oil, which matches the refractive index of the filter being used, is placed on a microscope slide. A section of the filter is then placed on the microscope slide, covered with more oil, and then fitted with a cover slide. The particles should cover only about 3 to 7 percent of the area in order to avoid overlapping of the particles. After preparation, the slides are transferred to the microscope. The Reichert Zetopan Microscope used with the Quantimet-720 Analyzer system has lenses available to give nominal magnifications from 40 to 400 times using a 10-power objective lens. The microscope image is transmitted into the Vidicon head (essentially a TV camera) and then transmitted to the Quantimet720 Analyzer. 
The Quantimet-720 Analyzer consists of a group of individual modules to display, digitize, and analyze the video data. The display module contains a screen to show the actual video image and the screen image of the detected image.

Various controls are available to adjust the detected image and present additional information on the screen. The standard display screen is divided by 625 horizontal and 800 vertical electronic lines. The difference between individual lines, called a picture point, is the basic measure in recording data. The actual size of the picture point may be calculated using a microscope micrometre slide. The system control module provides a method in which uneven light from the microscope can be balanced within the analyzer and the light intensity to the analyzer can be adjusted. The standard detector module provides the adjustments necessary to match the video microscope image to the detected image. It is also possible to differentiate between particles of different gray levels. The standard computer module provides the controls necessary to tell the analyzer which detected data are desired. Area, intercept, perimeter, and count data may be obtained. An automatic mode is also available in which the data acquisition is controlled by another module. Data are presented on the top of the screen. The size distributor module provides a set of 7 digiswitches which are used to set the size distributions used in counting particles. An automatic mode allows another module to control any or all of the digiswitches.

The variable frame and scale module contains switches to control the size of the usable area of the screen. The programer module contains a hardwaretype program board which is programed by screw-in plugs. With the size distributor and standard computer in the automatic mode, the analyzer is under the control of the programer, and the desired data may then be transferred to a teletype. Data received by the teletype may be printed and analyzed manually or punched on paper tape. The paper tape is reduced to reportable data using a Nuclear Data- 812 Computer and a program using assembly and NEUTRAN language. ${ }^{15}$

\footnotetext{
${ }^{15}$ Rudy J. Maes, Rocky Flats Plant. Private Communication. April 1974.
}

\section{ANALYSIS OF SURFACE CORROSION}

John K. Fraser and Davis F. Carpenter

\section{Summary:}

Abnormalities on plutonium $(\mathrm{Pu})$ metal surfaces are examined by photography, scanning electron microscopy (SEM), and transmission electron microscopy (TEM). The results of recent analyses of a small, corroded spot on a metal part are discussed and illustrate how these methods are used in determining the composition and cause or origin of the abnormal area.

\section{Experimental:}

The entire surface of a Pu metal sample that had a small visual discoloration was placed in a cell, which would provide radioactive containment, and was then photographed using a Polaroid@ MP-3 Land Camera and Polaroid P/N 55 film. This was done to provide a magnified, contrast field (black, gray, and white) of the corrosion area for documentation and to aid the analyst in selecting a representative sample site.

Small amounts of the residue from the darkened reaction area were removed using an orangew ood scraper and needlenose tweezers. The removed material was transferred to copper electronmicroscope grids, mounted on SEM stubs (sample holders), and analyzed by energy-dispersive X-ray spectroscopy in conjunction with SEM.

Photomicrographs of typical particles are shown in Figures 5 and 6. Electron diffraction analysis in conjunction with TEM was also performed.

The X-ray fluorescence elemental data on particles mounted on the copper grid in Figure 5 indicated primarily $\mathrm{Pu}$, lesser amounts of silicon, iron, and aluminum, and in some locations, traces of sulfur and tungsten. The TEM electron diffraction analysis indicated the light particles on the main particles in Figure 5 to be aluminum oxide and the matrix to be plutonium(III) fluoride. The X-ray fluorescence elemental data on a single corrosion particle shown in Figure 6 indicated primarily $\mathrm{Pu}$ and lesser amounts of titanium, iron, aluminum, and calcium. The TEM analysis indicated plutonium dioxide or an isomorph. The electron diffraction data obtained by TEM are not sensitive or specific 


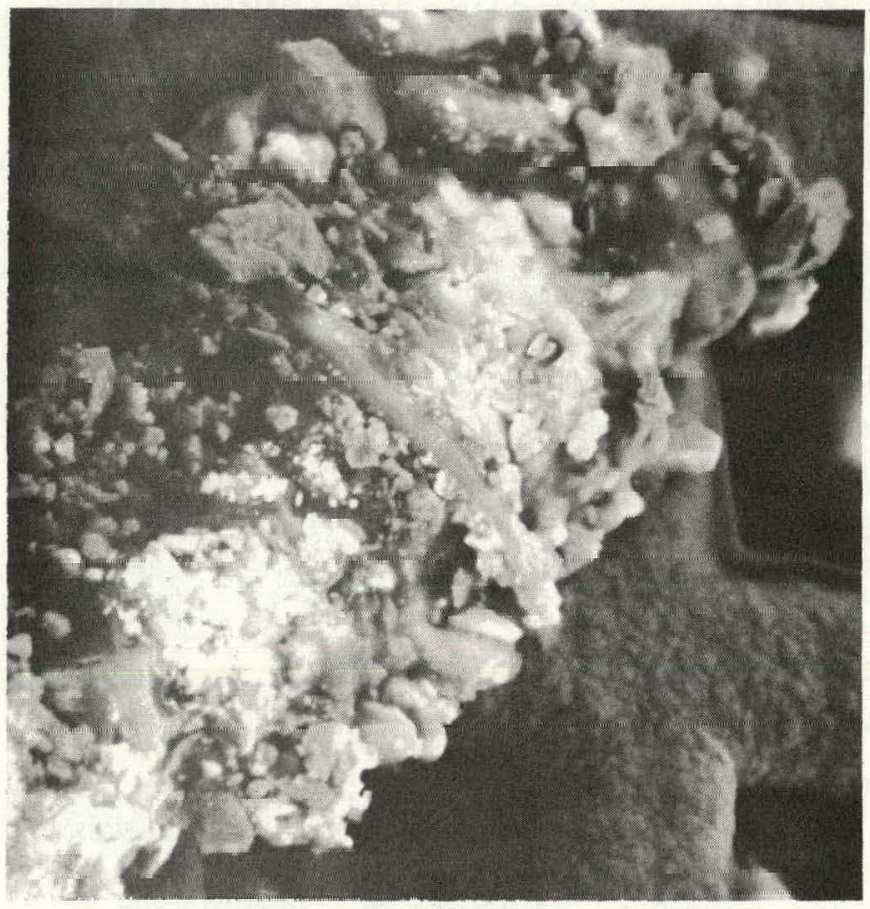

FIGURE 5. Corrosion Particles Mounted on a Copper Grid. Magnification Factor about 540X.

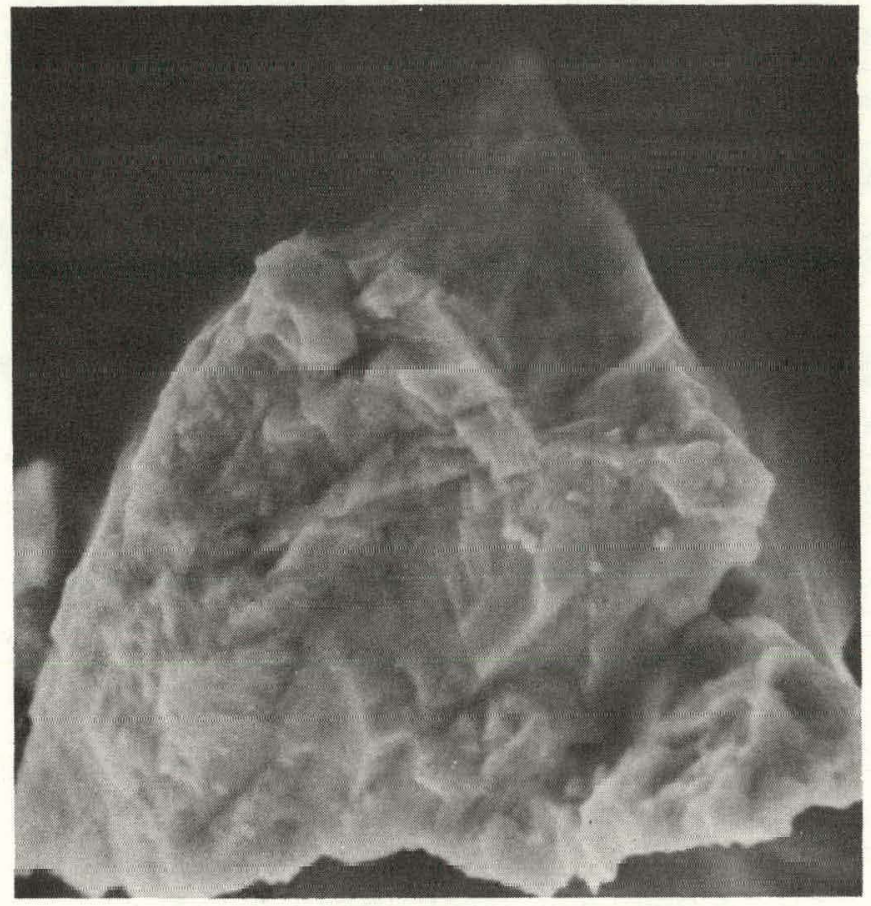

FIGURE 6. Single Corrosion Particle. Magnification Factor about 2670X. enough to determine differences between isomorphic compounds of $\mathrm{Pu}$.

The elemental composition, determined by X-ray fluorescence spectroscopy in conjunction with SEM, and specific compounds, determined by electron diffraction in conjunction with TEM, are often sufficient for describing the nature of corrosion or other abnormalities on Pu metal surfaces. The origin or cause of these surface changes can often be surmised from these analytical data or analyses supplemented with data from other techniques, such as X-ray diffraction.

\section{INVESTIGATION OF DEPOSITED PLUTONIUM SURFACES}

\section{Davis F. Carpenter}

\section{Summary:}

A study of deposited plutonium surfaces has been conducted with the electron microscope to meet the following goals: (1) Develop a safe, nondestructive method for exanination of pluturium $(\mathrm{Pu})$ surfaces, (2) Evaluate the reproducibility of texture of deposited surfaces with constant deposition parameters, (3) Gauge the variation in texture of the depnsited surface over large areas, (4) Appraise the effects of an oxygen-starved atmosphere on deposited surfaces as a function of time, and (5) Determine the mechanism of formation of various topographical features such as furrows, domes, and angular grains.

\section{Experimental:}

A goal for a safe, nondestructive method for examination of Pu surfaces was satisfied with the development of a unique replication technique. The technique consists of wetting one side of a Bioden plastic film with acetone and laying the wet side against the $\mathrm{Pu}$ surface. Rectangular Bioden films of $2.5 \times 10^{-3}$ centimetres $(\mathrm{cm})$ thickness and approximately 2 by $0.7 \mathrm{~cm}$ in length are soluble in acetone. Once the dissolved side of the film comes in contact with the 
surface, the Bioden-acetone solution flows and conforms to the surface topography of the $\mathrm{Pu}$. When the acetone evaporates, the film can be peeled away from the surface, providing a negative replica of the plutonium surface.

The replica is then coated with gold and examined in the electron microscope. Special electronic contrast-reversal techniques are used so that the image produced is a positive image of the original surface. Standard operating parameters are used in order that images from a variety of surfaces may be compared in a quantitative manner.

The following points summarize this experimental technique: (1) Replicas appear to provide a suitable method of surface examination. The replication technique is especially adapted to those cases where it is not possible to examine a surface directly; (2) The textures of deposited Pu surfaces are reproducible with constant parameters; (3) Considerable variation exists in surface texture as a function of location, and this texture variation is produced by thermal gradients across the deposited area; (4) The surface texture changes only slightly as a function of time in an oxygen-starved atmosphere; and (5) The furrows are a manifestation of machining marks left by the cutting tool in the substrate.

The domes are suspected to be caused by sharp irregularities in the machining marks. These irregularities could be caused by the cutting tool encountering abrupt density changes in the substrate. Foreign particles are also suspected to nucleate some domes. No hypothesis has been developed yet to explain the formation of angular grains. Enough additional information is expected to be collected in these and future investigations to determine what features constitute an ideal surface and to gain some insight on the proper mixture of parameters needed to achieve the most ideal surface.

\section{IDENTIFICATIOUN OF ASBESTOS}

\section{Davis F. Carpenter}

\section{Summary:}

Asbestiform materials are frequently encountered at Rocky Flats. Because of the potential health hazard, there is a need for characterization of these minerals. Transmission electron microscopy, coupled with selected area electron diffraction (SAED), is a viable method for identifying and counting asbestos fibers. The technique developed is specific for chrysotile or amphibole fibers and is capable of measuring the size of the fibers even though they may be only a few hundred angstroms in diameter.

\section{Experimental:}

Even though many varities of asbestos minerals exist, only six types are of commercial importance. ${ }^{16,17}$ These are chrysotile, which is a serpentine mineral, and amosite, tremolite, actinolite, crocidolite, and anthophyllite, which are amphibole minerals. Chrysotile, which constitutes about 95 percent of the world's production of asbestos, is in the form of small cylindrical crystals called fibrils. Fibrils are usually found bundled together to form fibers. Wide use is made at the Plant of materials that either contain or might contain asbestos minerals. These materials range from air-filter media to some of the talc used on surgeon's gloves. It is known that exposure to asbestos represents a health hazard. Thus an urgent need exists to determine fiber size distribution as well as concentration because toxicity dependence on size and mineral type has yet to be firmly established. The size range of fibrils and even many fibers extends to dimensions too small for optical microscopy. Most fibers found in the environment are less than 1 micrometre in diameter. It is understandable that transmission electron microscopy coupled with selected area electron diffraction (SAED) is considered to be the only viable method for identifying and counting asbestos fibers. The technique developed is specific with respect to identification of chrysotile or amphibole fibers and measures the size of the fiber even though it may be only a few hundred angstroms in diameter.

The highly magnified shadowgraph obtained in electron microscopy is for the most part an accurate

\footnotetext{
${ }^{16}$ Leslie Bartosiewicz. "Improved Techniques of Identification and Determination of Airborne Asbestos." Journal, American Industrial Hygiene Association 34:252. June 1973.

${ }^{17} \mathrm{~S}$. Holmes. "Developments in Dust Sampling and Counting Techniques in the Asbestos Industry." Annals of the New York Academy of Sciences 132:288. December 31, 1965.
} 
portrayal of the morphological aspects of an asbestos fiber. Chrysotile fibers are usually circular bundles of fibrils or round single fibrils. Often, these bundles or fibrils can be distinguished by the fact that they are tubular and the hollow center can be seen in the electron microscope image. This tubular appearance is characteristic of chrysotile but is not always present. Therefore, if a fiber does not appear to be hollow, this does not rule out that it is not chrysotile. Amorphous material can be attached to the surface or fill the tubes or both, thereby giving the appearance of being a solid fiber. Thus, the SAED technique is useful as an identification method to supplement the morphological information.

The SAED is imperative for identification of the amphibole minerals since nonasbestos materials can appear to be fibrous in that they may have a 3-to-1, length-to-width ratio. Also the nonasbestos sheet and plate silicate minerals fracture in the same general way as the asbestos minerals, so that again morphology does not lead to a reliable identification. Thus SAED has the advantage that the 2-dimensional pattern of diffraction spots of some asbestos fibers contain certain outstanding characteristics that can be recognized by a trained microscopist at a glance. This is especially true for the most common type of asbestos, the serpentine mineral chrysotile.

The SAED pattern of any chrysotile fiber is analogous to a rotating or oscillating crystal X-ray diffraction pattern in which the long dimension of the fiber tends to lie parallel or nearly parallel to the supporting membrane and is therefore perpendicular to the incident electron beam. This corresponds to the axis of rotation being normal to the beam in the usual type of rotating crystal X-ray exposure. In this type of X-ray pattern, the spots are arranged in lines, called layer lines, with the spacings between the lines dependent upon the distance between planes of atoms in the crystal. Similarly, the layer lines in SAED are also prominent, and their spacing reveals the atomic periodicity in the direction of the fiber axis. A cursory view of the layer-line spacing in the electron microscope allows the investigator to distinguish between chrysotile, tremolite, and amosite. These three forms of asbestos all have layer lines spacings corresponding to a periodicity of about 5.3 angstroms. This group of silicates can be distinguished from others, for example wollastonite, lizardite, antigorite, albite, hedenbergite, or diopsite, by layer-line spacing and spot spacing along the layer lines. For a full identification of the asbestos minerals, the characteristic arrangements of spots would have to be studied. The chrysotile pattern has prominent streaks on layer lines other than the central one, and some streaking also may be seen on the central one. These characteristics simplify identification of chrysotile and eliminate the need for detailed study of the electron diffraction pattern. The SAED technique provides rapid means of classification of asbestiform fibers. Not only are the types of fibers readily identified, but their size distribution can be determined as well. Sample preparation is generally simple. The substance is dispersed in water or acetone, and a drop is dricd on an electromesh carbon-coated grid. When the grid has dricd, it is sinply inserted into the microscope and examined.

\section{POROSITIES OF WELD PHOTOMICROGRAPHS}

\author{
John K. Fraser
}

\section{Summary:}

Photomicrographs of weld samples from batches of aluminum (Al) wire welds on beryllium (Be) parts are taken and subsequently analyzed for porosity areas using the Quantinel-720 Analyzer and epidiascope. The results of the porosity measurements are used as a quality contiul tesl fur verification of the batches of wire. Acceptance test criteria and details of the porosity methodology are given.

\section{Experimental:}

The results of the porosity measurements are one quality control criterion for acceptance or rejection of batches of $\mathrm{Al}$ weld wire for joining Be parts. Test welds, using batches of the $\mathrm{Al}$ wire to be certified, are made by the Joining Research and Development group, and photomicrographs of these welds are taken by the Metallurgy group. Three photomicrographs of welds from each batch are submitted to the Service Laboratory, and specifications require the mean porosity of the samples to be less than 3 percent, and 2 of 3 test welds to have less than 3 percent porosity. Porosity in the $\mathrm{Al}$ weld wire is observed on the photomicrographs as solid black 
areas. Dark-gray areas are due to shading or texturing of the sample and are not included in the porosity area. Inclusions, appearing as a light area surrounded by a black ring, also are not included in the porosity area. The porosity area is generally heterogeneous from one part of the photomicrograph to another, so the entire photomicrograph must be analyzed. Three basic units are employed in the analysis of these photomicrographs: (1) The Vidicon head which is a television camera transferring the video image from a microscope slide or epidiascope to the analyzer; (2) The Quantimet-720 Analyzer, which converts a video image to digital information such as area, perimeter, intercept, particle sizing, and particle counting; and (3) The epidiascope, an accessory to the analyzer, used to image photographic prints or transparencies or to analyze large objects by transmitted, incident, or dark-field incident illumination.

For the Al weld-wire porosity analysis, the photomicrograph is mounted face down on the epidiascope with the stage settings to zero along both the $\mathrm{x}$ and $\mathrm{y}$ axes. One corner of the photomicrograph is aligned to the corner of the analyzer screen, and by movement of the stage $x$-axis and $y$-axis controls, total alignment of the photomicrograph may be checked. The detected image on the analyzer screen is adjusted to match the epidiascope video image. Analyzer screen-size settings are adjusted to divide the photomicrograph into specific equal sections in order to fully cover the photomicrograph with no overlap. Epidiascope stage settings are then adjusted to a series of predetermined values, and the area measurement of each set is recorded from the printout on the analyzer screen. Percent porosity is calculated as the sum of the detected areas of each section of the photomicrograph divided by the total area, which is the number of sections analyzed multiplied by the dimensions of the screen size.

\section{RADIOMETRIC ANALYSIS}

\section{URANIUM-233 ANALYSES}

Richard A. Nixon

\section{Summary:}

Several types of uranium-233 $\left({ }^{233} \mathrm{U}\right)$ samples originating from the Chemistry Research and
Development group were analyzed by X-ray fluorescence spectroscopy and radiometric techniques, including alpha-particle spectroscopy and gamma-ray spectroscopy. The analyses included assay for ${ }^{233} \mathrm{U}$ in solid materials, determination of plutonium $(\mathrm{Pu})$ isotopes, and determination thallium-208 $\left({ }^{208} \mathrm{Tl}\right), \mathrm{a}^{232} \mathrm{U}$ daughter.

\section{Experimental:}

The solid samples of uranium oxide submitted for ${ }^{233} \mathrm{U}$ assay are dissolved in appropriate aqueous acidic media. After dissolution, X-ray fluorescence is used for samples containing $U$ in concentrations greater than 10 grams per litre $(\mathrm{g} / \mathrm{l})$, and radiometric analysis for samples containing $\mathrm{U}$ in concentrations less than $10 \mathrm{~g} / \mathrm{l}$. Assay results are reported as grams of ${ }^{233} \mathrm{U}$ per gram of solid sample $(\mathrm{g} / \mathrm{g})$.

For the X-ray fluorescence method, the relative accuracy and precision for ${ }^{233} \mathrm{U}$ is the same as for all uranium nuclides: accuracy $= \pm 2.2$ percent; precision $= \pm 3$ percent. There are no radiometric standards for ${ }^{233} \mathrm{U}$ available at Rocky Flats, but the relative accuracy and precision for ${ }^{233} \mathrm{U}$ should approximate that of the radiometric Pu method: accuracy $= \pm 10$ percent; precision $= \pm 5$ percent. The detection limit for ${ }^{233} \mathrm{U}$ is about $5 \times 10^{-5} \mathrm{~g} / \mathrm{l}$. All of the values given depend somewhat on the types of samples and the levels of $U$ present; for example, ${ }^{234} \mathrm{U}$ seriously interfers with the method.

Plutonium $238\left({ }^{238} \mathrm{Pu}\right)$ and both ${ }^{239} \mathrm{Pu}$ and ${ }^{240} \mathrm{Pu}$ are determined by alpha-particle spectroscopy in ${ }^{233} \mathrm{U}$ after extraction with 2-thenoyltrifluoroacetone. Then ${ }^{236} \mathrm{Pu}$ is employed as a tracer in this procedure, and $\mathrm{Pu}$ concentrations are generally in the parts per million range.

In order to process kilogram amounts of ${ }^{233} \mathrm{U}$ in unshielded facilities, the ${ }^{232} \mathrm{U}$ daughter must be separated from the ${ }^{233} \mathrm{U}$. The rate at which these daughters grow back determines the maximum time ${ }^{233} \mathrm{U}$ may be safely handled inside a glove-box line. The daughter growth rate is determined conveniently by measuring the concentration of ${ }^{208} \mathrm{Tl}$, which emits a 2.60-million electron volt (mev) gamma ray. Since there are no ${ }^{208} \mathrm{Tl}$ standards at Rocky Flats, the measurements are relative ones. Samples are 
taken in 4-dram glass vials before and after processing the ${ }^{233} \mathrm{U}$, and gamma-ray energies are counted every day for a week. The relative amounts of ${ }^{208} \mathrm{Tl}$ present is a measure of how fast the gamma levels were increasing in the processed uranium. ${ }^{18}$

The samples are counted about 2.5 centimetres $(\mathrm{cm})$ from an Ortec Low Energy Photon System (LEPS) lithium-drifted germanium [ $\mathrm{Ge}(\mathrm{Li})]$ detector of $2-\mathrm{cm}^{3}$ active volume in conjunction with a Nuclear Data -4420 pulse-height analyzer and a Canberra1413 amplifier. The total counts in the 2.60 mev-photopeak are used to measure the ${ }^{208} \mathrm{Tl}$ present. The amount of ${ }^{208} \mathrm{Tl}$ varies considerably from one batch of ${ }^{233} \mathrm{U}$ to another. 'The minimum value after the separation also varies appreciably, depending on how well the daughters are separated. The following values are typical of the efficiency of the separation: the activity of a sample taken before processing remained constant at 20,500 counts per 4000 seconds, while the activity taken afterwards decreased to 200 counts per 4000 seconds before beginning to increase. Since ${ }^{208} \mathrm{Tl}$ is determined as the relative amount of the nuclide present at different times after processing, rather than an absolute value, the accuracy of the method is not determined. The relative precision is \pm 10 percent.

\section{REVISED COMPUTER PROGRAM FOR DRUM COUNTING}

\author{
Harvey L. Bramlet
}

\section{Summary:}

Current computer software for the drum-counter system in the plutonium process facility has been revised to include additional teletype commands and paper-tape output of coded results for further computer processing. The changes simplify operations and speed data reduction without affecting the data values output.

\footnotetext{
${ }^{18}$ R. H. Rainey. Laboratory Development of a Pressurized Cation Exchange Process for Removing the Daughters of U-232 from U.233. ORNL-4731. Oak Ridge National Laboratory, Oak Ridge, Tennessee. December 1972.
}

\section{Experimental:}

The Nuclear Data® 4410 Pulse-Height Analysis Program Series 1060, 1061, and 1106 in assembly language was revised to simplify operations and speed data reduction. Since the teletype is separated by considerable distance from the computer control module, four routines were added to compensate for the loss of video display.

The first command, Time, sequentially prints marker positions, acquire time remaining, and preset time. The Restore command resets markers for a peak search. The Kill command erases spectra data in the computer. The Dead command starts acquisition and a special light on the teletype. This command also doubles as a check to determine if the computer is operating. An echo routine has been added so that a data-tape output could be produced with teletype input of 6 identification and counting codes. The tape is adequate for direct entry into the Hewlett-Packard computer. Previously, retyping of data had been required. The binary loader was relocated to avert its being overlaid. The loading procedure was simplified with addition of loading addresses and a routine to automatically check for imput errors. A 30-minute calibration procedure is no longer necessary each time the computer fails because a routine has been added to gencratc a 1-foot-long paper tape that contains the recalibration data.

\section{ANALYSIS OF SPECIAL UNITS}

\author{
Richard A. Nixon
}

\section{Summary:}

Site returns are routinely analyzed for isotopic composition by visual examination of the characteristic gamma-ray spectra of the nuclides involved. Special site returns that have been exposed to a neutron source off-site also have been examined for identification and quantitative determination of fission products. Zirconium $95\left({ }^{95} \mathrm{Zr}\right)$ and niobium 95 $\left({ }^{95} \mathrm{Nb}\right)$ are present at levels of about $1 \times 10^{-12} \mathrm{gram}$ per gram $(\mathrm{g} / \mathrm{g})$ in these units. 


\section{Experimental:}

Gamma-ray spectroscopy has been used for many years to analyze fission products, ${ }^{19}$ primarily in the processing of spent reactor fuel elements, fall-out from weapon testing, and environmental analysis of nuclear reactors. Recently, at Rocky Flats it has been necessary to analyze entire site-return units for two different purposes: (1) to insure the units are actually tuballoy, oralloy, or plutonium as claimed by the shipper; and (2) to determine fission products present in special site returns that have been exposed off-site to a neutron source.

The qualitative identification of metals or alloys composing the units is accomplished simply by visually checking the gamma-ray spectra for the presence of characteristic energy peaks that uniquely identify the nuclide involved. The special site returns are more difficult because these units require both the identification and quantitative determination of any fission products. This analysis is complicated by numerous, high-energy, low-intensity gamma energies of plutonium and americium because the fission products are present only in small amounts. To accomplish the analysis of these special units, it is convenient to analyze for ${ }^{95} \mathrm{Zr}$ and ${ }^{95} \mathrm{Nb}$, since they are both prominent in the fission-product spectrum and their gamma-ray energies are fairly free of interference. The relative abundance of other fission products may be calculated if the neutron-energy spectrum is known.

The samples analyzed to date have ${ }^{95} \mathrm{Zr}$ and ${ }^{95} \mathrm{Nb}$. levels of about $1 \times 10^{-12} \mathrm{~g} / \mathrm{g}$. The detection limit has not been determined but is appreciably lower than the $10^{-12} \mathrm{~g} / \mathrm{g}$ levels observed. If necessary, the detection limit could be considerably lowered by increasing the count time. The counting system consists of an Ortec Low Energy Photon System (LEPS) with a lithium-drifted gernaniün [ $\mathrm{Ge}(\mathrm{Li})$ ] detector of 2 cubic centimetres active volume, a Canberra-1413 amplifier, and a Nuclear Data-4420 pulse-height analyzer. The samples are contained in a pressure cooker and counted about 50 centimetres from the detector.

\footnotetext{
'F. Adams and R. Dams. Applied Gamma-Ray Spectrometry. Permagon Press, New York. 1970. Pages 299-304.
}

TABLE IV. Characteristic Gamma-Ray Energies of Nuclides in the Investigation of Fission Products in Special Units.

\begin{tabular}{|c|c|}
\hline Radioactive Nuclide & $\begin{array}{l}{ }^{*} \text { Characteristic Gamma-Ray Energy } \\
\text { (in kiloelectron volts) }\end{array}$ \\
\hline Uranium 235 & 185 \\
\hline Uranium 238 & 1001 \\
\hline Plutonium 239 & 374 (complex) \\
\hline Zirconium 95 & 724,756 \\
\hline Niobium 95 & 765 \\
\hline Cesium 137 & 662 \\
\hline
\end{tabular}

"Source: R. L. Heath. "Gamma-Ray Spectrum
Catalogue: Ge(Li) and $\mathrm{Si}(\mathrm{Li})$ Spectrometry."
ANCR-1000-2, Third Edition, Volume 2.
Aerojet Nuclear Company, Idaho Falls, Idaho.

The relative error associated with these analyses is about \pm 50 percent. There are no ${ }^{95} \mathrm{Zr}$ or ${ }^{95} \mathrm{Nb}$ standards at Rocky Flats, so the counting efficiency is approximated with a cesium-137 standard. The small sample load and low accuracy required have not justified the use of a more rigorous calibration method. Characteristic gamma-ray energies of the nuclides involved in these analyses are listed in Table IV. The largest error is self-absorption, even though the gamma-rays determined are fairly penetrating. The absorption in the walls of the pressure cooker are negligible compared to selfabsorption. Other errors common to radiometric analysis (such as geometry, reproducibility of sample position, and pulse pile-up) are of lesser importance for these samples.

\section{THERMAL ANALYSIS}

\section{IMPROVED SAMPLE LOADING FOR DIFFERENTIAL THERMAL ANALYSIS}

\author{
Patricia A. Hyman, Roger S. Cichorz, \\ and Paul B. Berry
}

\section{Summary:}

Sample loading for differential thermal analysis (DTA) has been improved by modifying the heater 
FIGURE 7. New Configuration of Heating Block Assembly.

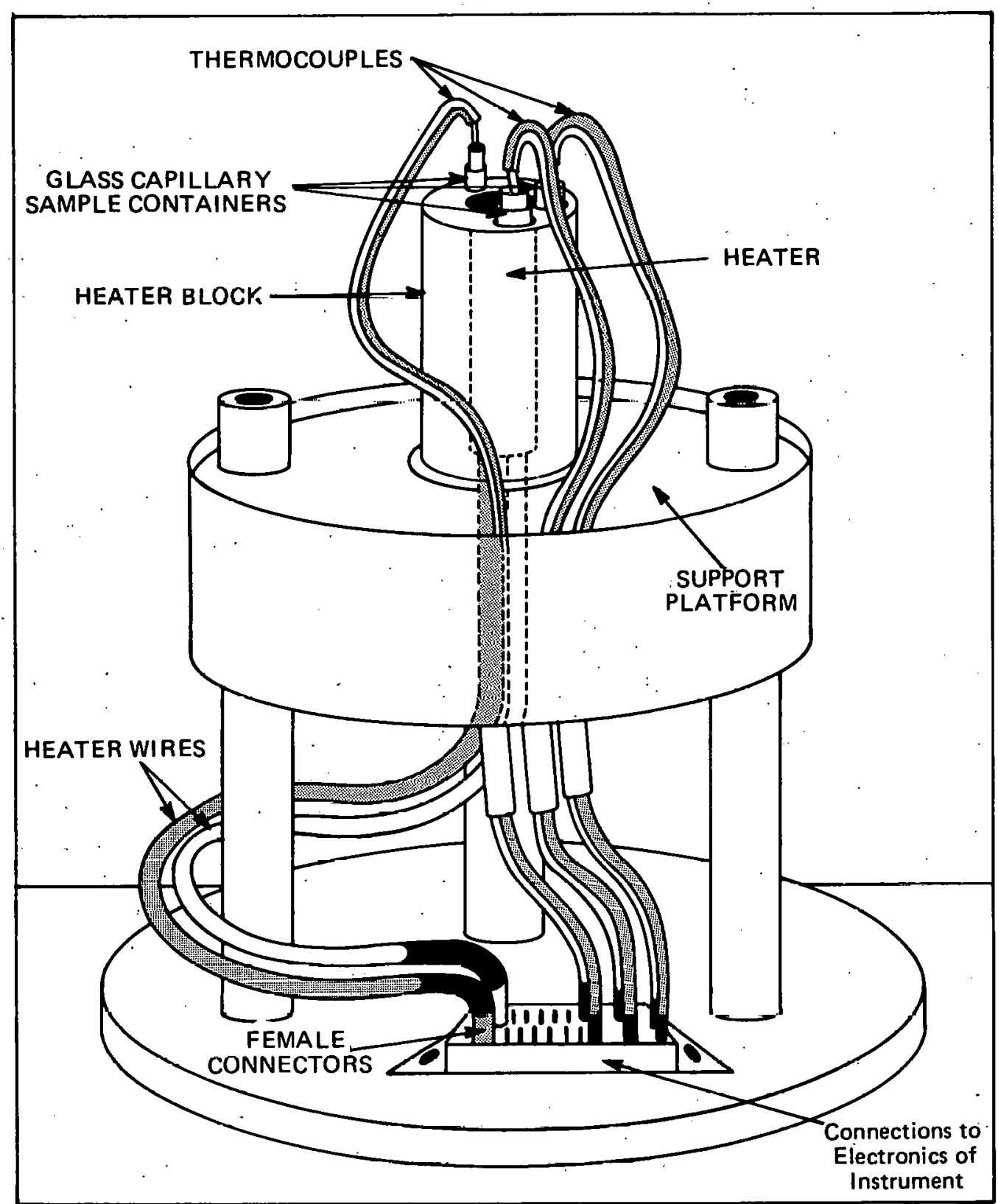


block wiring on a DuPont-900 Analyzer. The modification of the heating block assembly has shortened sample change time and has simplified the loading operation by eliminating clumsy wire manipulations. The time savings aspect is especially noticeable when handling samples inside a glove box.

\section{Experimental:}

Generally, 24 to 30 samples are run on the differential thermal analyzer at a given time. Almost as many (12 to 24) radioactive-contaminated samples are run at a given time inside a glove box. The manipulations required to change a thermally hot heating block, install a cool one, and load a sample are difficult for an operator wearing glove-box gloves. In an effort to minimize the clumsiness of the manipulations and to avoid the frequent breaking of glass capillaries and instrument thermocouples, an alternate wiring scheme for the heating block assembly was designed.

In the original assembly, the wires from the heater extended from the top of the heating block and through an opening in the support platform and were connected indirectly by flag connectors to the electronics of the instrument. The wires from the thermocouples passed through the same opening in the platform creating a clumsy congestion of wires that were extremely difficult to separate, especially for an operator wearing glove-box gloves.

Modifying the assembly involved removing the old heater from the block, drilling the center hole completely through the block, and replacing the flag connectors on the heater wires with female plug connectors. The wires are oriented so that they extend in the opposite direction from the sample holes in the heating block. In this new assembly, the heater wires extend down through a hole in the center of the platform away from the thermocouple wires. The heater wires are easily connected to the electronics of the instrument even by an operator wearing the thick leaded glove-box gloves. The modified assembly is depicted in Figure 7.

With the new configuration, a warm heating block is quickly and efficiently replaced by one that is at room temperature without disturbing the other wiring. Samples can be loaded quickly without breaking their glass capillary containment as there are no heater wires to interfere. The same operation inside a glove box on the old assembly often involved 15 to 20 minutes of operator time in manipulating wires, replacing broken thermocouples, and reloading lost samples. The same operation using the modified assembly is usually accomplished inside the glove box within 5 to 8 minutes and usually without mishap.

\section{THERMAL DECOMPOSITION OF ANION EXCHANGE RESIN WITH NITRIC ACID}

Roger S. Cichorz

\section{Summary:}

Differential thermal analysis (DTA) and infrared spectroscopy have been utilized in examining the thermal decomposition reaction of Dowex@ 1-X4 anion exchange resin in contact with 7 molar nitric acid. The experimental evidence indicates that the initial exothermic reaction observed in this system corresponds to oxidation of the organic resin by nitrate ion. Infrared spectroscopy provides a means for the qualitative characterization of changes occurring in the reacting species, while DTA provides a measure of the thermal stability of the system.

\section{Experimental:}

The DTA provides a relatively simple means for examining the thermal reactivity of individual compounds and mixtures of two or more substances. The method has been utilized at the Plant for several years to determine the thermal stability of ion-exchange resins mixed with varying concentrations of aqueous nitric acid $\left(\mathrm{HNO}_{3}\right)$ in order to assess reactivity hazards. Results obtained when the materials under examination are sealed within glass or quartz capillary tubes are judged to be more useful than those obtained from open capillary tests for the following reasons: (1) the substances undergoing testing are able to maintain intimate contact with one another within the capillary at all times, (2) volatility differences between test substances are not a consideration since they cannot escape the capillary, (3) the system can be examined at higher temperatures, 


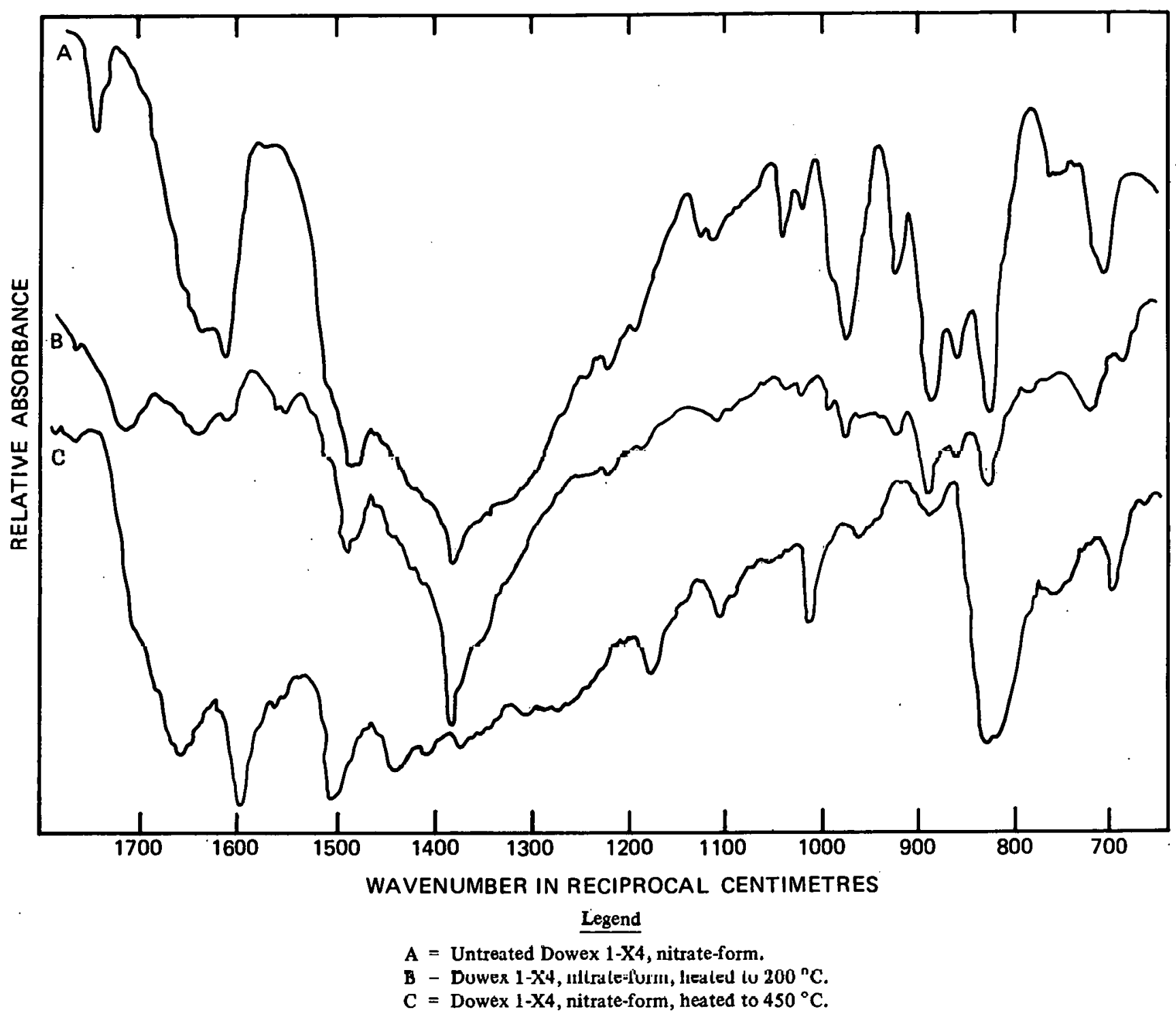

FIGURE 8. Infrared Spectra of Dowex-1 Resins.

(4) the effect of air on the reaction is minimized, (5) endotherms caused by aqueous transitions are absent, and (6) the onset and transition temperatures of exothermic reactions are more reproducible.

Recently, DTA was used to determine changes in thermal stabilities of a series of Dowex 1-X4 anion-exchange resins and Dowex $50-\mathrm{X} 8$ cationexchange resins that were subjected to gamma and alpha radiation or contacted with $\mathrm{HNO}_{3}$ or hydrochloric acid. The onset temperature of the initial exotherm provided a useful measure of the thermal stability of the resin system. In these resin investigations, infrared spectroscopy was used as a complementary method for examining the various resins for structural changes prior to DTA analysis. Although differences in the infrared spectra of acid-treated or irradiated resins revealed the types of structural changes that had occurred (for example, oxidation or nitration), the method was not suitable as a quantitative measure of the amount of degradation or the change in thermal stability that took place in the resin.

In a series of experiments with Dowex 1-X8 resin wetted with $7 \mathrm{M} \mathrm{HNO}_{3}$ the test resins were loaded on the differential thermal analyzer and allowed to proceed to a given temperature by programed heating. At some selected stage, the reactions were quenched 
by immersing the capillaries into liquid nitrogen, and the resins subsequently examined by infrared spectroscopy. In all experiments involving examination of the resins that had been quenched prior to the first exotherm, only minor degradation was detected. Resins that had proceeded into the first exotherm were marked with loss of water; deterioration in the nitrate-ion absorption, the presence of a carbonyl absorption at 1700 reciprocal centimetres $\left(\mathrm{cm}^{-1}\right)$, and changes in the relative intensities of certain absorption bands in the 1100 to $650 \mathrm{~cm}^{-1}$ region. Continued heating of resins beyond the first exotherm resulted in extensive oxidative degradation of the resin and complete depletion of the nitrate-ion absorptions at $1389 \mathrm{~cm}^{-1}$ and $821 \mathrm{~cm}^{-1}$. These changes are illustrated in the infrared spectra reproduced in Figure 8.

The infrared spectroscopy evidence overwhelmingly indicates the initial exotherm to be indicative of nitrate-ion oxidation of the organic polymer matrix. Continued heating of the resin- $\mathrm{HNO}_{3}$ mixtures leads to more extensive oxidation with concomitant. changes in the ionic nitrate species. Eventually, complete oxidative degradation of the organic polymer and disappearance of the nitrate ion occurs, and the infrared spectrum no longer bears any styrene-divinyl benzene (polymer matrix) character.

Interestingly, when these experiments were repeated with irradiated Dowex 1-X4 resins, similar results were obtained. After periods of irradiation with $\mathrm{HNO}_{3}$, some nitration had occurred as evidenced by the presence of carbon-nitrogen and nitrogenoxygen absorptions in the infrared spectra. The nitration mechanism was probably free-radical initiated, since nitration was only observed in cases where a radiation source is present. When these irradiated resins were subjected to DTA and quenching experiments, no further nitration occurred, and all chemical changes as evidenced by infrared spectroscopy were oxidations similar to those observed in the nonirradiated resins.

Infrared spectroscopy, used in conjunction with these DTA investigations, provided an effective means for qualitatively examining chemical changes occurring in the resin- $\mathrm{HNO}_{3}$ system. The two techniques provided an excellent means for examining a relatively complex reaction sequence and will be applied to future investigations of this sort.

\section{MISCELLANEOUS PROJECTS}

\section{NONDESTRUCTIVE METHOD FOR GALLIUM IN PLUTONIUM}

Harvey L. Bramlet

Summary:

New equipment selected for the automated nondestructive determination of gallium in plutonium metal by energy dispersive X-ray fluorescence is described. On comparable count times and samples, the standard deviation was improved from 0.050 on previous work to 0.0055 with the equipment. Using appropriate standards, the calibration was linear with a correlation coefficient of 0.9998: Recalculation of standards gave analyses with errors approximately equal to the uncertainty in the standards.

\section{Experimental:}

Most of the improved statistics are due to the equipment software selected for this work. A Rigaku power supply and generator were selected to support a molybdenum target X-ray tube. A Kevex® 0810 Automatic Sample Changer with a yttrium secondary target was used. The detector is a cryogenicallycooled lithium-drifted silicon type with excellent resolution. A PDP-1 1 Computer was used in a standard Tracor Northern $880 \circledast$ data analysis unit. System software from Tracor Northern was revised by Doyle of the Physical Metallurgy group to fit the needs of this project. ${ }^{20}$

Samples were standard metallographic mounts polished to at least 400 grit. The mount was wrapped with a $0.25-\mathrm{mil}$ Mylar $\circledast$ film and placed in the Kevex sample chamber for analysis. The software calculation of results was extensive. Basically, a ratio of gallium $\mathrm{K}_{\alpha}$ line counts to plutonium M-line counts was plotted versus known concentration. A typical recalculation of standards used in the curve is shown in Table V, and a 1000 second-count

\footnotetext{
${ }^{20}$ Joe H. Doyle. Private Communication. Rocky Flats Plant. April 1977
} 
TABLE V. Typical X-Ray Fluorescence Results for the Gallium Standards.

Standard 1 (Low)

0.001

(absolute error)

Standard 2 (Low)

0.002

Standard 3 (High)

0.010

Standard 4 (High)

0.004

Standard 5 (High)

0.011 statistical evaluation of 12 replicate analyses resulted in a mean of 1.0390 and standard deviation of 0.0055 .

\section{TRACE CYANIDES IN NATURAL WATERS}

\section{Delbert L. Ralphs and Clyde E. Michel}

\section{Summary :}

A rapid method involving the use of a silver-sulfide specific-ion electrode has been developed for the direct measurement of free cyanide ion $\left(\mathrm{CN}^{-}\right)$and complex cyanides in natural waters. The silver-sulfide electrode provides about an order of magnitude more sensitivity toward cyanides than the conventional cyanide specitic-ion electrode. 'l'he method elıminates the need for the time-consuming distillation step required in previous $\mathrm{CN}^{-}$determinations. The normal range for $\mathrm{CN}^{-}$by this method is 0.01 to 1.0 milligrams per litre, al though higher concentrations can be determined after appropriate quantitative dilutions.

\section{Experimental:}

Water samples are adjusted to 0.05 normal in sodium hydroxide, and a fixed amount of silver indicatorphosphate buffer solution is added. Any cyanide present shifts the equilibrium, decreasing the Ag-ion concentration which is then measured by a suitable $\mathrm{pH}$ meter employing the silver-sulfide specific-ion electrode and a double-junction reference electrode. Direct comparisons with cyanide standards are made, or, alternately, the method of additions may be desirable, particularly when the samples contain significant amounts of dissolved salts.

\section{WATERBORNE. EFFLUENT MONITORIN G Nolan E. Moody}

The annual revision of the Waterborne Effluent Monitoring program has been completed. All sampling points and required analyses are listed. Waterborne Effluent Monitoring is a summary of the joint efforts of the Environmental Sciences group and the General Laboratories of Rocky Flats to analyze and characterize various local water sources. Included are drinking water, waste effluents, natural streams, underground water, and the water supplies of surrounding communities. The annual revision is used as an instruction manual for sampling and analysis by the laboratories. The National Pollutant Discharge Elimination System permit points, sampling, and analysis by the Colorado and Jefferson County Health Departments are indicated. Additions, deletions, and corrections are made throughout the year on an informal basis. The typed revisions are issued in January of each year or more often if major changes are made.

\section{HYDROLOGIC TEST-HOLE PROGRAM Nolan E. Moody}

All analytical data generated on hydrologic test holes for the period of March 1974 through August 1976 lave leen elited and cunpiled intu a 200-paye booklet. Water samples from 43 hydrologic test holes are analyzed every 5 months by the Colorado Statc Health Department Laboratory and Rocky Flats General Chemistry Laboratory, and results are compared in this compilation. The purpose of the testing program is to determine if underground water is being affected by Rocky Flats operations and to monitor seepage from various Plant sources. State of Colorado and Rocky Flats personnel meet periodically to discuss the analytical results on each set of water samples. After initial meetings, it was apparent that the manner in which results were being 
reported was not satisfactory: (1) it was difficult to determine changes in ground-water composition when only the results from the previous 5 months were presented and discussed, (2) resolving analytical errors or differences depended more on memory than on fact, and (3) an historical record was needed. The compilation of 200 pages listing 57 water-quality parameters was produced in an attempt to meet these needs. Analytical results are added after each 5-month testing series. The compilation is used to detect analy tical errors, to determine if parameters should be added or eliminated, to compare analy tical results between the State and Rocky Flats laboratories, and to trace changes in the underground water system. The last use is of limited value, however, because of the massive amount of data and the large number of variables involved in an investigation of this sort. The compilation is available to persons interested in studying underground water and solar-evaporation pond seepage.

\section{MONITORING OF ACID GASES THROUGH PARTICULATE AIR FILTERS}

Tom L. McFeeters

\section{Summary:}

The atmospheres entering and leaving a bank of high-efficiency particulate air (HEPA) filters were monitored for trace gases resulting from hydrofluoric acid $(\mathrm{HF})$ and nitric acid $\left(\mathrm{HNO}_{3}\right)$ vapors entering the filter plenum. Variations in concentrations of $\mathrm{HF}$ and total acids in the pre-filter and post-filter air samples suggest that a portion of each acid gas retained in the filter does not react chemically with the HEPA filter media and bleeds off during periods of relatively low incoming acid-gas concentrations.

\section{Experimental:}

Air flowing through filter plenums in the plutonium processing facility contains trace quantities of acid gases from various line operations. Analysis of HEPA filter media indicates formation of nitrates and fluorides during filter usage. Air samples were simultaneously collected before and after one stage

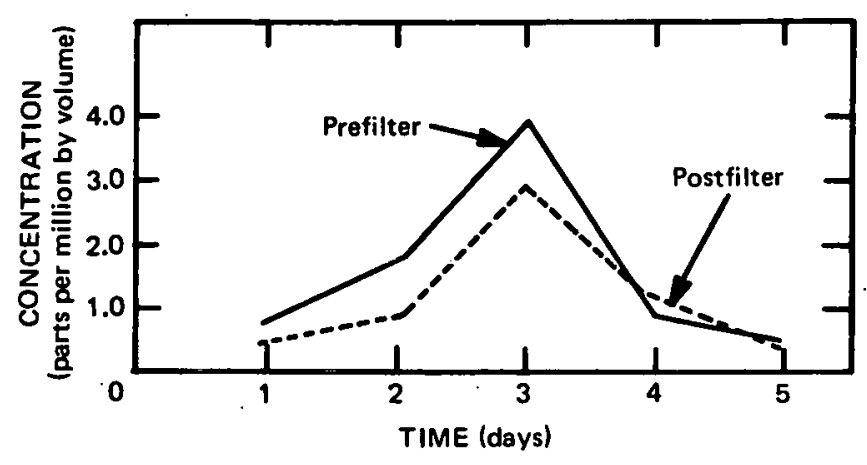

FIGURE 9. Hydrogen Fluoride Concentration.

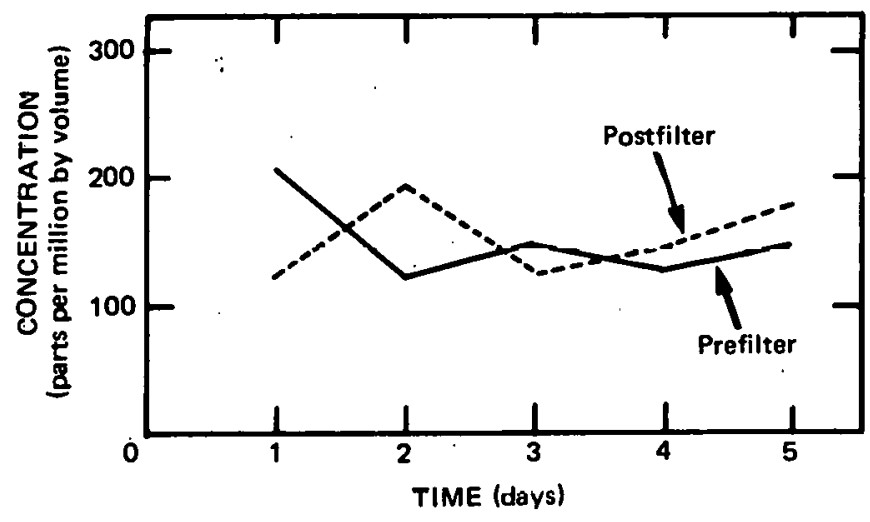

FIGURE 10. Total Acid Concentration.

of HEPA filters and analyzed for HF and total acidity. Comparison of upstream and downstream acid-gas concentrations would then provide some measure of the interaction between acid gases and filter media.

Gas samples were bubbled through 0.01 molar sodium hydroxide solution. Air quantities were measured by a calibrated rotameter downstream from the bubbler. After collection, the $\mathrm{NaOH}$ solutions were analyzed for fluoride ion $\left(\mathrm{F}^{-}\right)$by specific-ion electrode techniques to determine HF. Then acid-base titrations were performed to determine total acid gases. Analysis results are presented in Figures 9 and 10. In most cases, significant decreases in concentrations occur across the filter stage, showing the interaction of the acid gases with the filter media. When acid concentrations decrease significantly in the incoming air flow, the concentrations of acid gases leaving the filter may be higher than those entering. This 
effect is attributed to loading the damp filter media during periods of high incoming concentrations and subsequent bleeding off during low concentration periods. This indicates that not all of the acid gases retained by the filter have reacted chemically with the media, but rather are adsorbed and probably retained in solution on the damp media.

\section{CHARACTERIZATION OF EXPERIMENTAL FILTER ADHESIVES}

\author{
Keith J. Grossaint
}

\section{Suminury:}

Engineering standard specifications for high-efficiency particulate air (HEPA) filters for use in plutonium processing buildings have been under study by the Utilities and Filter Certification Departments at Rocky Flats. Present specifications ${ }^{21}$ provide for air-quality standards, but improvements in the service life of filters (particularly in nitric acid environments) and disposal techniques are desired. A part of the study involves survey of several types of adhesivesealants proposed by filter vendors. The adhesives are used to bind the media and gaskets to the filter frame and to seal the frame edges and joints. The Service Laboratories have provided information to 'characterize the adhesives' resistance to chemical attack, thermal degradation properties, flammability (autoignition), and formulation for quality acceptance tests. A suggested scheme for future testing has been derived from these results.

\section{Experimental:}

The adhesives characterized included those based on rigid foam polyurethane, plasticized urethane, neoprene, and silicone resins. They were submitted by Flanders Filter Company, American Air Filter Company, Mine Safety Appliances Company, and Solfiltra Corporation. The composition of the HEPA filter constituents, including the adhesive resins, organic additives, and inorganic filters and additives, were determined by mass, infrared, and

\footnotetext{
${ }^{21}$ Carroll Amos. "Standard for HEPA Filters, General Purpose." Rocky Flats Plant Standard SMU-401. Rocky Flats Plant, Rockwell International, Golden, Colorado. September 1975.
}

emission spectroscopic techniques. The analysis results are summarized in Table VI.

All of the resins investigated, except silicone, exhibited visible signs of reaction with concentrated (greater than 8 molar) nitric acid $\left(\mathrm{HNO}_{3}\right)$. The urethane foams developed a reddish discoloration, and became brittle after air drying. The neoprene resins developed a dull-brown color and brittle surface crusts. Inorganic additives and vulcanizing agents collected as white precipitates on some surfaces. The interior of the neoprene and plasticized urethane adhesives retained resiliency. Apparently their closed cell structure permitted only limited penetration of $\mathrm{HNO}_{\mathrm{g}}$ The nnly nhserved effect of acid treatment on the silicone sample was a slight absorption of acid solution (about 0.2 weight percent).

Reaction with the acid produced organonitrate products for the polyurethane foams based on toluene-diisocyanate and for the neoprene formulation, which included a polyglycerol resin. No indication of organonitrates was detected for the silicone or from the plasticized polyurethane (methylenediphenylene diisocyanate based). Other evidence of $\mathrm{HNO}_{3}$ attack included generation of nitrogen dioxide and its dimer (dinitrogen tetroxide), carbon dioxide, and carbon monoxide. The results of $\mathrm{HNO}_{3}$ treatment are summarized in Table VII.

The susceptibility to failure from exposure to heat was determined by flameless autoignition testing. New resins were compared to resins reacted with nitric acid and then air dried. The temperature of ignition by heated air (and pure oxygen used to simulate highly-concentrated or pressurized air) was shown to decrease to the 150 to $200{ }^{\circ} \mathrm{C}$ range following reaction with acid. Ignition of new resins was not observed below $370^{\circ} \mathrm{C}$, and in most instances was not ohserver to the upper temperature limit of the test equipment $\left(>500^{\circ} \mathrm{C}\right)$. These temperatures compare with the 25 to $80^{\circ} \mathrm{C}$ temperatures expected for exhaust plenum gases, and $88^{\circ} \mathrm{C}$ required to activate most plenum fireprotection alarms and water-sprinkler systems.

Thermal degradation was exhibited in the form of decomposition, volatilization, and, in some instances, deformation by apparent melting or viscous flow. The melting occurred for the plasticized urethane, 
TABLE VI. Composition of Adhesive-Sealants in Filters.

Adhesive Resin

Rigid Urethane Foam (Manufacturer A)

Rigid Urethane Foam (Manufacturer B)

Neoprene

Plasticized Urethane

Silicone (RTV-116)@
Organic Components

toluene-diisocyanate

resorcinol-propyleneglycol ether

methylene diphenylamine

extensive free isocyanate groups

dichlorodifluoromethane (blowing agent)

phenoxypropanol

phenol

possible ethyldichlorophenylurethane

toluene-diisocyanate

propyleneglycol

methylene diphenylamine

carbon dioxide (blowing agent)

free isocyanate groups

chloroprene

di-tertbutyl phenol

di-tertbutyl cresol

glycerol ester

toluene, acetone, methyl ethyl ketone (solvents)

methylenediphenylene diisocyanate

aromatic phosphate esters (triphenyl, tricresyl, etc.) fatty hydroxy acid (curing agent) (probable diglycolic acid ester of castor oil)

hindered phenols (di-tertbutyl phenol, etc.)

triethyl phosphate (trace)

dimethyl silicone
Inorganic Components

silicon dioxide

none detected

magnesium oxide antimony oxide

zinc borate

calcium oxide

TABLE VII. Effects of Reaction of 8 to 12 Molar Nitric Acid with Filter Adhesives.

Resin

Rigid Urethane Foam

(Manufacturer A)

Rigid Urethane Foam (Manufacturer B)

Neoprene

Plasticized Urethane

Silicone (RTV-116)®
Visible Effects

Discolored red, embrittled, and slight shrinkage.

Rapid absorption of solution.

Evolution of nitrogen dioxide dimer.

Discolorcd rcd, embrittled, and slight shrinkage.

Free isocyanate groups destroyed.

Evolution of nitrogen dioxide dimer.

Discolored brown, crust formed on surface, and embrittled on surface.

Shrinkage (result of dissolution of plasticizer in nitric acid) and emurittled on surface.

Originally buoyant and eventually absorbed water and sank.

Discolored red-brown.

Slight absorption of acid solution.
Chemical Effects

Nitroaniline and nitrophenol formed.

Nitroaniline and ammonium nitrate formed.

Oxidized organics (carbun dioxide, possible acetic acid), nitroethanol, nitrophenol, nitroglycol, light hydrocarbons, magnesium nitrate, and antimony nitrate.

No nitro-organics detected.

No detectable effects. 
TABLE VIII. Autoignition-Testing Results of Filter Adhesives in Oxygen and Air Atmospheres.

Adhesive Resin

Rigid Urethane Foam

(Manufacturer A)

Nitric Acid-Treated Rigid Urethane Foam (Manufacturer A)

Rigid Urethane Foam

(Manufacturer B)

Nitric Acid-Treated Rigid Urethane Foam

(Manufacturer B)

Neoprene

Nitric Acid-Treated Neoprene

Plasticized Urethane

Nitric Acid-Treated Plasticized Urethane

Silicone (RTV-116)®

(No change on nitric acid treatment)
Observed Temperature of Smoke Evolution

$$
\left({ }^{\circ} \mathrm{C}\right)
$$

Charred; no visible smoke in either oxygen or air.

125 (Oxygen)

185 to 400 (Air)

300 (Oxygen)

300 (Air

185 (Oxygen)

185 (Air)

370 (Oxygen)

375 (Air)

185 to 490 (Oxygen)

185 to 480 (Air)

380 (Oxvęen)

380 (Air)

Ignition Temperature

$$
\left({ }^{\circ} \mathrm{C}\right)
$$

$>470$ (Oxygen)

$>400$ (Air)

163 (Oxygen)

$>400$ (Air)

485 (Oxygen)

$>500$ (Air)

190 (Oxygen)

$>450$ (Air)

$>500$ (Oxygen)

$>450$ (Air)

185 to 490 (Oxygen)

$>500$ (Air)

>\$4! (Oxygen)

>S4i) (Air)

150 (Oxygen)

390 (Air)

385 (Oxygen)

$>550$ (Air)

FIGURE 11. Thermogravimetric Analysis Results for Plasticized Urethane Resin.

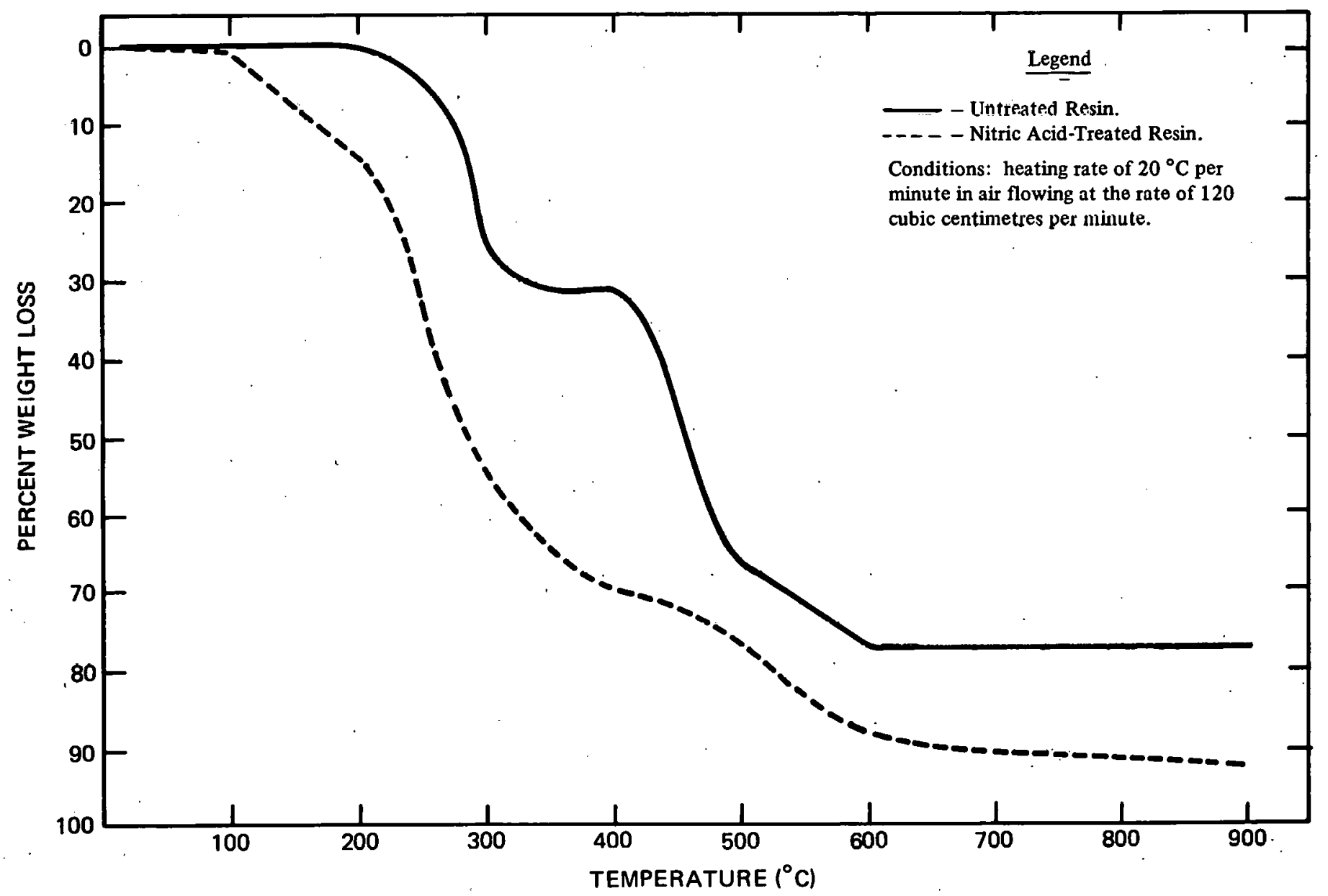




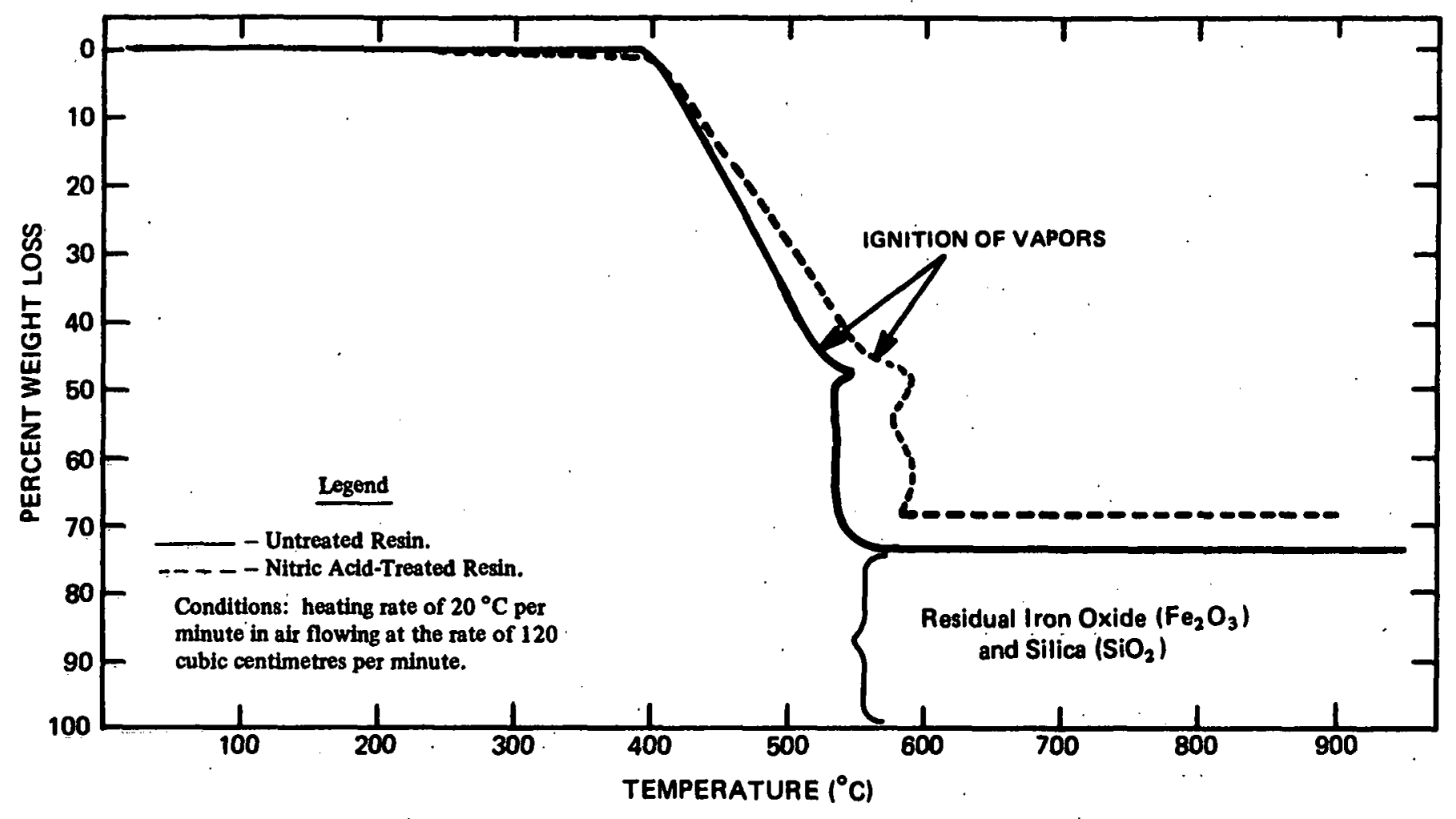

FIGURE 12. Thermogravimetric Analysis Results for Silicone Resin.

and coincided with the temperature range of volatilization of the phosphate ester plasticizer $\left(350\right.$ to $510^{\circ} \mathrm{C}$ ). The silicone was degraded by oxidation, evolving vapors in sufficient concentration to ignite in the air flow of the thermogravimetric and autoignition tests at temperatures near $370^{\circ} \mathrm{C}$. The gases evolved from the urethane and neoprene adhesives appeared to be nonflammable to $400{ }^{\circ} \mathrm{C}$. This effect was attributed to the nature of the decomposition gases (amine or amide radicals and phosphate esters). In all cases the $\mathrm{HNO}_{3}$-treated resins evolved smoke and ignited at lower temperatures than untreated resins. The observed autoignition temperatures were still above the temperature of the plenum fire-protection system. These results are summarized in Table VIII. Thermogravimetric analysis (TGA) results for the untreated and $\mathrm{HNO}_{3}$ treated plasticized urethane and silicone resins are illustrated in Figures 11 and 12, respectively.
Differential thermal analysis results were not definitive and exhibited only slight indications of exothermic reactions above $125^{\circ} \mathrm{C}$ for the $\mathrm{HNO}_{3}$ treated samples.

The analytical results and intended use of the product adhesives suggest the following format for testing of HEPA filter adhesives: (1) Identification of the adhesive formulation to the extent that any changes would be detectable by routine analysis; (2) Thermal degradation by thermogravimetric analysis and autoignition testing; (3) Tensile strength of the bond for the filter frame, media-to-frame, and media-to-media; (4) Porosity for resistance to acid penetration, as well as the required barrier to particulates; and (5) Acid resistance, specifically $\mathrm{HNO}_{3}$ degradation, including comparison of: shape (e.g., swelling, shrinkage), flexibility, and formation of potentially hazardous organonitrates. 
RFP-2644 